\title{
Wealth Inequality, Educational Environment and School Enrolment: Evidence from Mexico
}

Using data from the extended section of the 2010 Mexican census $(2.9$ million households), we study how school enrolment is associated with wealth inequality and with the educational environment the child is exposed to at the household and municipal levels. We provide robust evidence of wealth inequality as a negative predictor of school enrolment for children in primary, secondary and high school age ranges while a positive role is played by the educational environment. Through the introduction of interaction terms, we account for how economic and educational variables are intertwined at both the household and the municipal level, and we are able to illustrate the considerable heterogeneity in the role of adult education for households at different standards of living.

Keywords: wealth inequality, school enrolment, education, Mexico

\section{Introduction}

A number of recent contributions have put a spotlight on economic inequality, on its upward trend in the last decades and on the implications this has for our societies; these include academic articles (Kanbur \& Stiglitz, 2016; Neves, Afonso, \& Silva, 2016; Piketty, 2015; Saez \& Zucman, 2016) as well as successful books addressing the general public (Milanović, 2016; Piketty, 2014; Stiglitz, 2012; Wilkinson \& Picket, 2010). Among the social outcomes of major interest for academics and policymakers is education, which is a key component of human capital, an engine of growth, a universal human right, and a domain featuring in the most widespread multidimensional indices of societal progress, as well as in the main global development initiatives (e.g. Human Development Index, Multidimensional Poverty Index, Millennium Development Goals, Post2015 Sustainable Development Goals, etc.). Shedding light on the relationship between economic inequality and educational outcomes is important; if a negative relationship exists between the two, greater inequality would be associated with lower educational outcomes and therefore bear a significant cost for societies. 
In this paper we investigate wealth inequality as a predictor of school enrolment in Mexico. A body of literature which crosses the fields of economics, sociology and child development explores how educational outcomes may be affected by economic variables (e.g. Basu \& Van, 1998; Galor \& Zeira, 1993; Gutiérrez \& Tanaka, 2009; Mayer, 2001) and by the educational environment the child is immersed in (Crane, 1991; Cunha \& Heckman, 2007; Grolnick \& Slowiaczek, 1994; Strulik, 2013). We contribute to the literature by studying the association between wealth inequality and school enrolment through an empirical analysis which uses large scale data and goes beyond the mere incorporation of economic and educational variables by explicitly accounting for how these are intertwined. In particular, we contend, and our evidence confirms this hypothesis, that not only are economic variables and educational environment important predictors of school enrolment, but they also interact with one another and they do so at both the household and the wider levels (i.e. within and beyond the household). Accounting for such interconnections improves our estimations and enables us to illustrate how the role of adult education in enhancing child educational outcomes may vary for households at different standards of living. In this way, we also contribute to a fuller understanding of the demand side of education, which has a large potential for policy intervention (Handa, 2002) and whose importance for developing countries is advocated by the recent work of Lincove (2015).

Our empirical analysis uses cross-sectional data from the extended-questionnaire section of the 2010 Mexican census, which covers around 2.9 million households and is statistically representative at municipal level (the lowest political and administrative level in Mexico). We study the probability that a child is enrolled in school using multilevel logit models where the dependent variable is the dichotomous status of being enrolled/not being enrolled in school for children aged between 6 and 18. In order to allow for the possibility that enrolment dynamics may differ at different age levels, we investigate separately the three subsamples which correspond to primary, secondary and high school ages - i.e. the 6-12, 13-15 and 16-18 age ranges, respectively. For each of the three age ranges, we find strong evidence of wealth inequality as a negative predictor of school enrolment. Our results are robust to the adoption of alternative estimation strategies (logit and linear probability models with standard errors clustered at municipal level) and different inequality indices (Gini, Theil and Atkinson), as well as to the split of our sample by child gender and standard of living. 
The interplay between economic and educational variables is modelled through two interaction terms - one between household wealth and the maximum years of formal education attained by a household member and one between wealth and educational attainments in the municipality. Both interaction terms are highly significant and improve the ability of our models to fit the data; in addition, the one at municipal level also proves to be crucial for determining the sign and significance of wealth inequality. The nuances of how the educational environment relates to school enrolment at different levels of wealth for our three age ranges are graphically described by plotting average predicted probabilities of enrolment. A final offer of our paper relates to municipal random effects. The use of multilevel models enables us to provide illustrations of how municipal effects on school enrolment can differ substantially, even in the case of contiguous municipalities.

The remainder of the paper proceeds as follows. In section 2 we lay out the conceptual framework for our analysis, with a focus on the ways in which economic inequality and the educational milieu surrounding the child at both household and wider levels may affect school enrolment. In section 3 we outline our empirical strategy by describing the models we employ, the data we use, the derivation of our wealth indicator and the explanatory variables included in our estimations. In section 4 we present our results, focusing first on our main results and then discussing additional insights and municipal heterogeneity. In the final section, we summarise and conclude by highlighting the main lessons and policy implications stemming from our study.

\section{School enrolment: economic inequality and the educational environment}

\section{2.a Economic inequality and education}

The potential impact of economic inequality on school enrolment has been traditionally discussed in the literature by looking at both the demand and supply of education. With regard to the latter, the channel is a political economy mechanism whereby quality and quantity of the provision of a certain public good depend on citizens' willingness to contribute to it through taxation. Within this argument, the existence of inequality would lower the amount of resources available for the public provision of education because the rich would send their children to private schools and would try to forgo contributing to the funding of public education 
(Epple \& Romano, 1996). This would result in a lower supply of public education with negative effects on schooling - see Tanaka's (2003) model and its extension developed by Gutiérrez and Tanaka (2009).

With regard to the demand side, the bulk of the literature addressing the effect of inequality on schooling focuses on access. Galor and Zeira (1993) show that the distribution of wealth is important because, given the imperfection of credit markets and therefore the existence of glitches in borrowing opportunities, in an economy where wealth is held by a few only a minority will be able to invest in education. Similar results are obtained by Perotti (1993), García-Peñalosa (1995), Chiu (1998) and Checchi (2003), although for Perotti and García-Peñalosa the role of inequality may be positive for very poor economies. The focus of these papers is affordability of education and the economic barrier to enrolment, an argument which is expressed clearly in Basu and Van's (1998) 'luxury axiom', whereby education would be "a luxury good in the household's consumption in the sense that a poor household cannot afford to consume this good" (p. 415). Along these lines, overall inequality may be detrimental to school enrolment if it jeopardises poverty reduction, as indeed Iniguez-Montiel (2014) showed to be the case for Mexico.

Further mechanisms relate to a series of phenomena, attitudes and behaviours which are corrosive to the social fabric and are shown to be more likely to occur in more unequal societies. A fast-growing multidisciplinary literature shows that economic inequality is associated with lower levels of trust, social cohesion, civic engagement, agreeableness, as well as increased levels of individualism, self-enhancement and various sorts of antisocial or unethical behaviour. ${ }^{\mathrm{i}}$ It can be argued that economic inequality may have an impact on the demand of education through these channels when one considers that education is valued not only for instrumental reasons such as gaining a better wage, but also for intrinsic reasons such as becoming a better person in society (Reid, 1998). By triggering dynamics which are prejudicial to social coexistence, the potential effect of inequality on the demand of education for intrinsic reasons can be hypothesised to be a negative one; for example, Dincer (2011) shows a positive relationship between schooling and trust. As for the instrumental motivation, the effect of inequality on school enrolment may be negative if inequality within society fosters a myopic approach to lifetime consumption which prioritises immediate, over future, material gratification; 
alternatively, it may be positive if investment in education is perceived as a tool for climbing the economic ladder (Topel, 1997; Welch, 1999).

\section{2.b The relevance of the educational environment}

While undoubtedly important, economic factors are only part of the story and other variables affect educational outcomes (Cameron \& Heckman, 2001; Ray, 2000). We focus in particular on the educational environment the child is immersed in, both within and beyond the household - in particular, the level of education possessed by adults in the household and in the municipality. We maintain that not only is the educational environment important at both levels, but that it also interacts with economic variables - in our case, household wealth and mean municipal wealth.

\section{2.b.1 Educational attainments of adults within the household}

The importance of the educational environment surrounding the child in the household is well documented. Connelly and Zheng (2003), Dostie and Jayaraman (2006) and Bhalotra (2007), among others, provide sound quantitative evidence from developing countries that parents' education is a strong a predictor of children's educational outcomes. Handa (2002) finds that increasing parents' education has a far greater potential for boosting enrolment in a developing setting than raising household income. Basit (2013) shows that the positive role on educational achievements also extends to family members in the household other than the parents. A number of reasons have been given by educational specialists for the relevance of the educational environment within the household. The influential work of Grolnick and Slowiaczek (1994) argues that children's school achievement is affected by three components of parents' involvement - personal (caring about school), cognitive (exposing the child to intellectual stimulating material) and behavioural (attending school events), and that all three are directly or indirectly positively related to parents' education. The beneficial effect of parents' education on pupils' academic achievements through education-oriented values, involvement and ability to help with homework (whether objective or perceived) is also illustrated by the work of Davis-Kean (2005) and Hornby and Lafaele (2011).

We hypothesise that the level of education of adults in the household interacts with economic status, i.e. that its effect varies at different levels of household wealth. The dynamics behind this interaction are complex and this interaction can occur in a number of ways. For an illustrative example, consider the following pairs of 
households: i) two equally affluent households A and B, where in A adults are well educated and gained their wealth through professional jobs (e.g. surgeon or lawyer) while in B they have very little formal education and manage a restaurant; ii) two households $\mathrm{C}$ and $\mathrm{D}$ where all adults hold a university degree, but while $\mathrm{C}$ has become wealthy through highly paid jobs D has not. It is clear that there will be no difference between A and $\mathrm{B}$ in terms of affordability of education, or between $\mathrm{C}$ and $\mathrm{D}$ in terms of the education-related environmental factors described above. However, the confluence of educational and economic accomplishments in the case of $\mathrm{A}$ and $\mathrm{C}$ is likely to enhance the belief in material returns on schooling, which would yield a motivational premium for children to demand education as well as for parents to act in order to extend their children's duration of schooling.

\section{2.b.2 Educational attainments of adults beyond the household}

The conceptual underpinnings for the relevance of the wider educational environment lie in the notion that individuals' behaviour is influenced by those around them - see Crane's (1991) 'epidemic' approach to school dropout and Kling, Liebman and Katz's (2007) study of neighbourhood effects on educational outcomes. Evidence from Mexico of the existence of neighbouring effects on schooling decisions is provided by Bobonis and Finan (2009) and Lalive and Cattaneo (2009). The motivational component has a key role in Jencks and Mayer's (1990) socialization theory whereby adults in the neighbourhood act as role models, as well as in Strulik's (2013) framework where the aggregate behaviour of the community promotes the establishment of pro- or anti-schooling norms. A more educated environment can also be an incentive to stay in education for the desire to culturally fit in society, to meet higher educational requirements on the job market and for educational assortative mating purposes (Blossfeld, 2009; Nielsen \& Svarer, 2009). In addition, similarly to Grolnick and Slowiaczek's (1994) cognitive aspect of parents' involvement, Cunha and Heckman (2007) argue that a more educated environment also fosters children's learning and academic achievements thanks to the intellectual stimuli the child is exposed to.

As was the case for the household level, we hypothesise that educational and economic variables interact also at a wider level. To see the rationale for hypothesising an interplay between educational aggregates and mean municipal wealth, the role of the latter as an explanatory variable for individual school enrolment should first be clarified. It is widely recognised that in models which explain individual-level social outcomes (e.g. 
individual educational attainments, health status, life satisfaction, etc.) by means of both individual and aggregate economic variables (e.g. household and municipal income or wealth), the aggregate variables play the role of relative disadvantage or relative deprivation - see, inter alia, Luttmer (2005) and Gravelle and Sutton (2009). Following McLoyd (1990), Mayer (2001) and Hackman, Farah and Meaney (2010), relative deprivation is expected to negatively affect educational outcomes by decreasing children's willingness to study or stay in school, lowering parents' expectations and increasing stress due to lower social rank. Mayer (2001) contends that relative deprivation can lead to isolation and alienation; similarly, a link between relative deprivation and social exclusion can be found in Sen (1983) and Bossert, D'Ambrosio and Peragine (2007). As argued by Mayer (2001), isolation may affect the adherence to the norms and the absorption of the values which are prevailing in society. If this is the case, then the relevance of the mechanisms related to the educational environment discussed above can be expected to vary at different levels of relative deprivation. For example, the strength of role model (Jencks \& Mayer, 1990) or schooling norm (Strulik, 2013) mechanisms as motivational drives for demanding education will presumably be lower for more relative deprived and alienated individuals.

\section{Empirical operationalization}

\section{3.a Econometric strategy}

The willingness to investigate school enrolment using explanatory variables at both household and aggregate levels poses an estimation challenge which needs to be dealt with. Observations' independence can be questioned because children living in the same municipality share contextual factors, which are important for school enrolment and vary across municipalities (e.g. cost of schooling, quality of education, etc.). When the observations are not independent, one of the basic assumptions behind multivariate regression is violated because residuals are not uncorrelated. Overlooking this clustering leads to an underestimation of standard errors and a bias in results, with a higher probability of a type I error (Moulton, 1986, 1990). One option to deal with this problem is to use customary models with standard errors clustered at the suspected level of nonindependency, which provide reliable estimates through increased confidence intervals accounting for 
correlation between observations in the same cluster. Another option is to estimate multilevel (also called 'hierarchical') models with varying aggregate-level intercept terms, which model within-cluster error correlation directly and allow for the estimation of residual components at each level in the hierarchy. Given that we have a large number of clusters (2,452 municipalities), in our case both methods are viable (Bryan \& Jenkins, 2016; Cameron, Gelbach, \& Miller, 2008; Wooldridge, 2003). We opt for multilevel models because, in addition to allowing the correct estimation of standard errors, it also provides estimates of municipal random effects (Gelman \& Hill, 2009; Scott, Simonoff, \& Marx, 2013), which we employ to provide a graphical illustration of the spatial heterogeneity in school enrolment across municipalities. We carry out a log-likelihood ratio test for the null hypothesis that the variance of the estimated municipal random intercepts is zero - i.e. that there is no significant difference between the data fit of multilevel models vs models where clustering is unaccounted for. ${ }^{\text {ii }}$ For each of our models the test confirms that the clustered structure of our data is relevant and not accounting for this clustering would be erroneous. Finally, to ensure that our results are not contingent on the choice of multilevel logit models, for all our specifications we also run customary logit models and linear probability models where standard errors are clustered at municipal level. These models confirm our results and are available upon request.

Our dependent variable is the individual-level dichotomous status of being enrolled/not being enrolled in school for children aged 6-18. In order to allow for the possibility that enrolment dynamics may differ at different age ranges and to detect this heterogeneity, we split our sample into three subsamples corresponding to typical primary, secondary and high school ages and investigate them separately. This means that for each specification we will estimate three models based on different samples - the subsamples of pupils in the 6-12, 13-15 and 16-18 age brackets. In Mexico children are expected to start primary school at age 6, secondary school at age 13 and then move to high school, with both secondary and high school lasting three years. Attending secondary school is mandatory but enforcement is weak; attending high school was made mandatory in 2011 (the year after the census was carried out), and as in the case of secondary school there is no effective mechanism to enforce enrolment. It should be noted that, while it seems reasonable to split our sample according to these age groups, we do not assume that all pupils aged 6-12, 13-15 and 16-18 enrolled in school are in fact enrolled in primary, secondary and high school, respectively - the census only asks whether the 
pupil is enrolled in school or not. In addition, while the described $3+3$ scheme is the general rule applying to the very large majority of schooling patterns in Mexico, it is possible to find secondary schools or high schools which last 4 years. It can also happen that some students enter school late or repeat years, as noted by the Mexican Secretariat of Public Education (SEP, 2012).

Our level-1 explanatory variables of interest are household wealth and education. The latter enters our analysis as the maximum years of formal schooling among the adults in the household - results are unchanged if this variable is replaced by the average years of education in the household. Our wealth variable is an asset index constructed using information on the quality of the dwelling (such as floors, walls and ceilings), access to basic utilities (source of water, rubbish collection and sewage) and durable asset ownership (for example, computers, mobile phones and cars). The index is computed using principal components analysis (PCA) on the correlation matrix of the indicators as for Filmer and Pritchett (1999); in particular, we follow the procedure derived by Kolenikov and Angeles (2009) which better accounts for the discrete nature of the indicators used. ${ }^{\mathrm{iii}}$ The correlation between our municipality mean asset index and the official municipality mean income estimated by the governmental agency Consejo Nacional de Evaluación de la Política de Desarrollo Social (CONEVAL, 2013) is reassuringly high: 0.81 for linear correlation and 0.91 for rank correlation. Our level-2 (municipal level) explanatory variables of interest are municipal wealth inequality, mean municipal wealth and a variable labelled as 'Ratio' accounting for the educational environment at municipal level. Wealth inequality is measured using the Gini coefficient, which ranges from 0 to 1 for, respectively, minimum and maximum level of inequality, and which can be intuitively interpreted as the extent to which a distribution departs from equality. We create three 'Ratio' variables tailored on the role model or schooling norm which is most directly relevant for each age-specific model; hence, for our models addressing age ranges 6-12, 13-15 and 16-18 we employ, respectively, the ratio of adults in the municipality having completed primary school (Primary Ratio), secondary school (Secondary Ratio) and high school (HighSchool Ratio) - each Ratio variable is derived by dividing the number of individuals possessing the relevant level of education by the number of individuals not possessing it. 
In addition to these variables, we include the set of controls which are typically used in the literature on school enrolment in developing countries (Connelly \& Zheng, 2003; De Carvalho Filho, 2012; Dostie \& Jayaraman, 2006; Gumus, 2014). Our control variables include child's gender, age, whether she is indigenous, or she has a physical or mental disability, number of boys and girls in the household, whether the household is a beneficiary of a social program and characteristics of the household head such as gender, age and age squared. Controls at municipal level include municipality size, number of schools per child and outward migration intensity to the United States of America. ${ }^{\text {iv }}$

Formally, we consider the probability of enrolment as a random variable following a binomial distribution: $Y_{i} \sim B\left(n_{i}, \pi_{i}\right)$,

with binomial denominator $n_{i}$ and probability of success $\pi_{i}$. The probability of school enrolment for children $i$, living in household $h$, clustered in municipality $a$, is estimated as the logit of the underlying probability $\pi_{i h a}$ as a linear function of an array of explanatory variables:

$\operatorname{logit}\left(\pi_{i h a}\right)=\alpha+\beta_{1}$ Wealth $_{h}+\beta_{2} \operatorname{MaxEdu}_{h}+\beta_{3}\left(\right.$ Wealth $\left._{h}\right)\left(\right.$ MaxEdu $\left._{h}\right)+\delta_{1}$ Gini $_{a}+\delta_{2}$ Ratio $_{a}+$ $\delta_{3}\left(\operatorname{Gini}_{a}\right)\left(\right.$ Ratio $\left._{a}\right)+\gamma \operatorname{CONTROL}_{i h a}+\zeta_{a}+\mu_{i h a}$.

Wealth $h_{h}$ is the wealth of the household $h, \operatorname{MaxEdu}_{h}$ is the maximum years of education found in the household and $\left(\right.$ Wealth $\left._{h}\right)\left(\operatorname{MaxEdu}_{h}\right)$ is the interaction between these two variables. At the municipal level, Gini $_{a}$ represents inequality as measured by the Gini coefficient, Ratio $o_{a}$ is the ratio of people with a certain level of education to those without that level of education and $\left(\operatorname{Gini}_{a}\right)\left(\right.$ Ratio $\left._{a}\right)$ is the interaction between these two variables. CONTROL $L_{i h a}$ includes the individual, household and aggregated level variables used as controls (see Table 1 for their full list and description). In our multilevel model, $\alpha$ is the overall national intercept and the $(2,452)$ municipal level intercepts are obtained through the algebraic sum $\alpha+\zeta_{a}$. The $\beta$ 's, $\delta$ 's and $\gamma$ 's are our estimated coefficients and $\mu_{i h a}$ is the composite uncorrelated error. 


\section{3.b Data}

We use data from the extended-questionnaire section of the 2010 Mexican census (Instituto National de Estadistica y Geografia, INEGI henceforth, 2010), which is statistically representative at municipal level and covers around 2.9 million households. Looking at Table 1, one can see that $49.5 \%$ of children in our age range of interest are girls, a fifth is indigenous and $1.8 \%$ suffers from a disability. The household head is on average 44 years old and is a female in one sixth of total households. As expected, enrolment rates are notably different across the three age groups. Almost $96 \%$ of children in primary-school age attend school; this rate drops to $82 \%$ for children in secondary-school age and it dramatically decreases to less than $50 \%$ for adolescents in high-school age. The lower enrolment rates for older children is not surprising; there is a greater expectation that they work and for them staying in school has a higher opportunity cost given that they can obtain higher salaries. The need to contribute economically to the household is a major determinant of school dropout in Mexico; for example, Alcaraz, Chiquiar and Salcedo (2012) find that an increase in school dropout was determined by the need to counter the decrease in remittances from the United States to Mexico in 2008-2009.

\section{[Table 1 about here]}

The spatial heterogeneity of our municipal level variables can be appreciated by looking at Figures 1 , which displays two national maps of Mexico created by the authors on the basis of the INEGI (2010) data used. The first map (left panel) shows average school enrolment rates across municipalities (children aged 6-18 combined, darker municipalities indicating higher enrolment), while the second map (right panel) reflects the variability in wealth inequality (darker municipalities indicating greater inequality). It can be noticed that while there are clusters of neighbouring municipalities having similar figures, at the same time there are also municipalities where figures for these variables differ considerably from those of their neighbours. The picture of marked spatial disparities emerging from Figure 1 tallies with the evidence on economic inequality in Mexico described in OECD (2016a, 2016b). Not only does Mexico, together with Chile, feature at the top of OECD countries in terms of income inequality with a Gini coefficient exceeding 0.45 (and consistently so over the past decade), but it is also the country with the highest regional differences in per capita income, measured by the range between the richest and the poorest regions. 


\section{Results}

\section{4.a Main results}

Results from our multilevel logit estimations are presented in Table 2. Two specifications are estimated for each age bracket; specifications (1)-(2), (3)-(4) and (5)-(6) refer to the 6-12, 13-15 and 16-18 age ranges, respectively, and for each specification we report both raw coefficients and average marginal effects. Unlike specifications (1), (3) and (5), specifications (2), (4) and (6) include the interaction between adult educational attainments in the municipality and municipal wealth in line with the arguments laid out in our conceptual framework.

\section{[Table 2 about here]}

As can be seen in Table 2, household wealth and educational environment (at both household and municipal levels) are strong predictors of individual school enrolment $(p<0.001)$; the wealthier the household and the greater the amount of education surrounding the child, the higher the probability that she is enrolled in school. The significance $(p<0.001)$ with negative sign of mean municipal wealth points to the role of relative deprivation, which as we saw above is expected to be detrimental for school enrolment via its motivational and aspirational effects on both children and parents. ${ }^{\mathrm{v}}$

As to the Gini coefficient, while insignificant in specification (1) and (3) and positively significant in (5), it is constantly negative and significant $(p<0.001)$ for all age ranges once the interaction between municipal wealth and the adult educational attainments is included - i.e. for all of specifications (2), (4), (6). Interacted terms are statistically significant $(p<0.001)$ and specifications (2), (4), (6) neatly outperform specifications (1), (3) and (5) according to a number of goodness of fit statistics which are widely used to discern which among competing models best captures the variability in the data - see bottom rows of Table 2. Particularly meaningful in our case is the Bayesian Information Criterion (BIC), because it penalises models more heavily for the use of additional regressors, making it more demanding for specifications with interaction terms to be preferred to those without. According to the criteria developed by Kass and Raftery (1995), the degree to which specifications (2), (4) and (6) are to be preferred to (1), (3) and (5) according to the BIC is 'very strong'. Figure 
2 shows graphically the predictive role of the Gini coefficient, with curves derived from specifications (2), (4) and (6) displayed on the same graph for expositional convenience. The left panel shows that the probability of enrolment indeed declines over the inequality domain, and more markedly so for older children; the right panel shows that marginal effects are negative and significant for all age ranges (no confidence interval overlaps with zero, not shown here to keep the graph tidier) and are, as expected, more pronounced for older children. The negative coefficient for inequality is in line with the predictions of the models by Chiu (1998) and Checchi (2003), as well as of those of Perotti (1993) and García-Peñalosa (1995) for countries which are not at a very low level of economic development (as is the case for an upper-middle income country like Mexico), and does not offer support to the idea of economic inequality as an incentive to accumulate human capital. Kearney and Levine's (2016) recent paper offers a possible explanation for this; inequality may trigger a sense of marginalisation in disadvantaged children which leads them to underestimate returns to education and hence to lower their investments in human capital formation - in a country like Mexico, this feeling is possibly reinforced by the fact that routes to higher economic status often abstract from meritocracy and legality.

\section{[Figure 2 about here]}

We carry out a number of robustness checks. Table 3 presents specifications (2), (4) and (6) estimated replacing the Gini with the Atkinson and Theil inequality indices - specifications (2A), (4A), (6A) and (2T), (4T), (6T), respectively. As can be seen in the table, the negative and significant sign of wealth inequality is confirmed using these alternative indices. In Table 4, we find further confirmation of the negative predictive role of inequality when the analysis is carried out by subsamples; specifically, the result holds for gender subsamples [specifications $(2 \mathrm{G}),(4 \mathrm{G}),(6 \mathrm{G})$ for girls and $(2 \mathrm{~B}),(4 \mathrm{~B}),(6 \mathrm{~B})$ for boys] and for households below or above median wealth [specifications $(2 \mathrm{P}),(4 \mathrm{P}),(6 \mathrm{P})$ for poorer households and $(2 \mathrm{R}),(4 \mathrm{R}),(6 \mathrm{R})$ for richer households]. Finally, all the above results are confirmed if we replace our multilevel models with logit and linear probability models with standard errors clustered at municipal level (available upon request).

[Table 3 about here]

[Table 4 about here] 
Looking more closely at economic and educational variables at household level, it can be noticed that all the specifications reported in this paper include the interaction term between household wealth and mean education of adult in the households. These specifications outperform those without this interaction term as to their ability to fit the data, and including this interaction term does not influence sign or significance of the other regressors (results without this interaction term are available upon request). The interplay between household wealth and educational level sheds further light on the existence of a socio-economic gradient on school outcomes. The interaction term is significant $(p<0.001)$, giving an indication of its overall relevance; nonetheless, an interpretation which solely relies on summary statistics such as coefficient and significance levels can be misleading in nonlinear models because these can differ at different values of the covariates (see Ai \& Norton, 2003; Greene, 2010). ${ }^{\text {vi }}$ Following the suggestion of Greene (2010), we show graphically the behaviour of interacted explanatory variables by plotting the average predicted probabilities that our dependent variable takes a value of 1 (the child is enrolled in school) along the domain of one interacted variable at different levels of the other interacted variable.

In particular, Figure 3 below shows for the three age ranges average predicted probabilities of school enrolment over the household educational domain at different levels of household wealth - each level of household wealth is represented by a specific curve, based on specifications (2), (4) and (6). It can be seen that, for all age ranges and for each level of household wealth, predicted probabilities increase with mean education in the household. In addition, as expected, these probabilities are higher for children in richer households. It should be noted that beyond these common features there are specific patterns and idiosyncrasies across the three age ranges. While being enrolled at age 6-12 is almost a certainty for richest households (the relevant curves are basically flat and equal 1 over the whole educational domain), it is not so for less wealthy households - the probability of enrolment falling below $70 \%$ for children in households with low wealth and formal education. Interestingly, school enrolment becomes a certainty regardless of wealth when mean household education exceeds high school level; this shows how for early school enrolment lack of economic wealth can be to some extent compensated by the 'educational wealth' possessed by the household. In the case of the 13-15 age range, wealth-based differences in predicted probabilities tend to be mitigated at higher levels of household education, to the point that they tend to converge only at the very end of the educational spectrum - at educational levels 
which for poorest households are mostly off-sample. With regard to the 16-18 age range, wealth-based differences in the probability of enrolment are more marked in the middle of the educational spectrum; this suggests that for this age group, heterogeneity in school enrolment is greater among households in the middle of the socio-economic ladder than among those at the top or at the bottom - where presumably still being in education is, respectively, very common and very uncommon. Finally, it can be noticed that while for wealthy households the curve is concave along the whole domain, for most households it is initially convex before turning concave; this indicates that for high school age, potential benefits of an additional unit of adult education in the household may be initially increasing rather than decreasing.

\section{[Figure 3 about here]}

\section{4.b Additional insights and municipal random effects}

Additional insights emerge from other explanatory variables. Being a girl rather than a boy seems to increase the probability of being enrolled in school, in particular for the 16-18 age range; this is consistent with the general reversal of the educational gender gap in Latin America (World Bank, 2012). The negative coefficient for household size, wealth being controlled for, captures how resources need to be stretched among more family members, reducing resources available for investing in education. Having a disability lowers the probability of being enrolled, while the opposite holds for being a beneficiary of a social program and the availability of schools (in particular for children beyond primary school age). The negative sign of child age for the 13-15 and 16-18 age ranges reflects greater opportunity costs for older children to be enrolled in school; the positive sign for the 6-12 range is mainly driven by the greater likelihood of enrolment for children aged 8, 9 and 10 compared to younger children (some children enrol in school late), while at age 11 and 12 drop-out dynamics start coming into play decreasing the probability of enrolment. ${ }^{\text {vii }}$ The negative coefficient for female household head is not surprising because in most cases such characteristic in Mexico identifies single-mother households. Similar to Debowicz and Golan (2014), we find some evidence that school enrolment increases with the age of the household head - possibly because older parents are more mature, or tend to spend longer time engaging in educational activities with their children (McWayne \& Melzi, 2014). 
The level of outward migration can have a positive or a negative effect on investment in education (see HalpernManners, 2011). On the one hand, remittances increase disposable income at home, relieving economic barriers to education (Edwards \& Ureta, 2003); on the other hand, living in a municipality with high migration may disincentivise investment in education because greater connections with migrants increase migration opportunities and human capital acquired in Mexico tends to be poorly remunerated in the United States (Massey \& Espinosa, 1997). In line with the results of López-Córdova (2005), we find that outward migration is a positive predictor for younger children and a negative predictor for older children - in addition, our estimations split by gender suggest that the negative effect may be stronger for boys, as described by McKenzie and Rapoport (2011).

Finally, we find that being indigenous is a negative predictor of school enrolment. While this result may not surprise, it should be noted that Attanasio, Meghir, and Santiago (2012) find that, ceteris paribus, indigenous children are more likely to be enrolled in school than non-indigenous children. We do find an exception to the negative patter which is prevailing in both our pooled-sample and split-sample estimations, namely the positive sign for the indigenous dummy in regressions (4B) and (6B). A potential explanation for this is that indigenous boys benefit from a double advantage compared to their non-indigenous counterparts. First, they live predominantly in rural areas, which have been the target of massive educational expansion (Santibañez, Vernez, \& Razquin, 2005; UNESCO, 2007). Second, in indigenous families investment in education is concentrated on boys, with girls being expected to perform household chores along traditional gender roles (Rocha \& Latapí, 2016; Saraví, Abrantes, \& Bertely-Busquets, 2014).

We now turn to the analysis of municipal random effects. In Figure 1 above we illustrated how enrolment rates vary across municipalities; clearly, this simple illustration does not take any correlates into account - a municipality may have higher enrolment rates due to a richer educational environment, greater school availability, etc. The analysis of municipal effects emerging from our estimations enables us to report on the differences in the probability of enrolment across municipalities which remain after all our explanatory variables are controlled for. More precisely, consider that the right hand side of our econometric models can be simplified as $\beta_{0}+\beta \mathrm{X}+\beta_{\mathrm{j}}$, where $\beta \mathrm{X}$ refers to the vector of explanatory variables and their estimated 
coefficients, while $\beta_{0}$ and $\beta_{\mathrm{j}}$ are two constant terms. The former represents the country-level intercept and the latter is a parameter which is specific to municipality $j$; in other words, in the calculations of their predicted probabilities all individuals in the sample share parameter $\beta_{0}$ and all individuals living in municipality $j$ share $\beta_{\mathrm{j}}$. A positive (negative) value of $\beta_{\mathrm{j}}$ implies a positive (negative) contribution to the probability of enrolment due to living in municipality $j$. Figure 4 plots the $\beta_{\mathrm{j}}$ 's for the 2,452 Mexican municipalities in our models, arranged on the horizontal axis simply on the basis of their municipality code. As can be seen, there is a considerable spatial heterogeneity in the contribution to the probability of enrolment given by the municipal random effect. We report the names of two municipalities in each panel to give an examples of how highly different random effects can be found for municipalities within the same state.

\section{[Figure 4 about here]}

In Figure 5 we illustrate the spatial heterogeneity in the probability of enrolment by focusing on a geographically restricted case study. In this figure, we plot predicted probabilities for three children of primary school age who are identical in all respects other than the municipality they live in ${ }^{\text {vii }}$-these are Guadalajara (the capital of the state of Jalisco) and two adjacent municipalities in the Guadalajara Metropolitan Area, namely Zapopan and Tonalá. In this way, any difference in their predicted probability curves is determined by unobserved factors related to the municipality children live in. We plot probabilities of enrolment at different values of household wealth, so that we can see what happens to differences between municipalities at different points of the household wealth distributional spectrum. As can be seen in Figure 5, living in the capital or in Zapopan produces virtually no difference in the probability of being enrolled in school; conversely, living in Tonalá brings about a sizeable reduction in predicted probabilities. This reduction is particularly noticeable for poorer households, while for wealthy ones the differences across municipalities lessens.

[Figure 5 about here] 


\section{Conclusions}

Taking advantage of the large dataset provided by the extended section of the 2010 Mexican census, we have carried out an empirical analysis of the determinants of school enrolment. Our main explanatory variables of interest are wealth inequality and the educational environment surrounding the child within and beyond the household. In line with the conceptual framework we have drawn on the basis of economic, sociological, educational and psychological literatures, our results provide robust evidence of wealth inequality as a negative predictor of school enrolment and of a positive role played by the educational environment. Our work contributes to the literature also by highlighting the importance of accounting for how educational and economic variables are intertwined - both within and beyond the household. The introduction of interaction terms between economic and educational variables improves the ability of our models to fit the data, and graphical analysis of interacted variables shows considerable heterogeneity in the predictive role of adult education for households at different standards of livings. Last but not least, our evidence illustrates the disparity in the probability of being enrolled in school across municipalities, shedding important light on the character of spatial inequalities in Mexico.

Our contribution raises important issues for researchers to take forward and offers valuable insights to policymakers. On the first count, natural extensions of our work would be to explore the relationships we found using datasets containing individual income, polytomous measures of educational outcomes (test scores, grades, etc.), or to focus on higher education. We also hope our work encourages future research on educational inequalities, in particular with the aim of disentangling contextual effects of economic inequality (impinging on everyone in an unequal society) from those related to relative deprivation (affecting those lagging behind more successful others). Our interest in the interaction between municipal-level economic and educational variables motivated our use of mean wealth, but abstracting from this specific issue a valuable perspective can be gained by adopting idiosyncratic indices of relative deprivation - able to differentiate the level of relative deprivation experienced by individuals or households at different standards of living.

On the second count, our work highlights at least three issues for policymakers. The first is that economic disparities are detrimental to school enrolment; this suggests an education-based motivation for supporting 
redistributive policies. At the same time, as recommended by Mayer (2010), these should be accompanied by specific measures targeting directly those socio-economic profiles for which access to schooling is found to be problematic and school dropout more likely; in this respect, our evidence points to households which are economically deprived, single-mother headed, with numerous children, etc. Secondly, our work also strengthens the idea that the benefits accruing from extending education are cumulative across generations. Increasing the level of education of today's children will in turn boost that of tomorrow's children; our research indicates that if average adult education within the household were around high-school level this might enable virtually $100 \%$ enrolment rate of children in primary school age. In addition, enhancing the attainment of high school level education for adults would yield increasing returns for the enrolment of pupils in the 16-18 age range for a wide proportion of households. A target of universal high school education for the new generations may currently seem utopian, but it is a goal which Mexico, as an upper-middle income country, OECD member and net contributor to a number of United Nations agencies, cannot but take seriously. A final issue for policymakers to be aware of, and concerned with, is the disparity in the probability of being enrolled in school across municipalities. An effort should be made to tackle the sources of inequality in school enrolment illustrated in this paper. Education cannot be a prize for the children who are lucky enough to pick the right ticket in the lottery for the municipality they live in, or for the parents they are born to. 


\section{References}

Ai, C., \& Norton, E. C. (2003). Interaction terms in logit and probit models. Economics Letters, 80(1), 123129. https://doi.org/10.1016/S0165-1765(03)00032-6

Alcaraz, C., Chiquiar, D., \& Salcedo, A. (2012). Remittances, schooling, and child labor in Mexico. Journal of Development Economics, 97(1), 156-165.

Attanasio, O. P., Meghir, C., \& Santiago, A. (2012). Education choices in Mexico: Using a structural model and a randomized experiment to evaluate PROGRESA. Review of Economic Studies, 79(1), 37-66. https://doi.org/10.1093/restud/rdr015

Bank, W. (2012). World Development Report 2012: Gender Equality and Development. Washington, DC.

Basit, T. N. (2013). Educational capital as a catalyst for upward social mobility amongst British Asians: a three-generational analysis. British Educational Research Journal, 39(4), 714-732. https://doi.org/10.1080/01411926.2012.677414

Basu, K., \& Van, P. H. (1998). The Economics of Child Labor. American Economic Review, 88(3), 13861388. https://doi.org/10.1257/aer.89.5.1386

Bhalotra, S. (2007). Is Child Work Necessary? Oxford Bulletin of Economics and Statistics, 69(1), 29-55. https://doi.org/10.1111/j.1468-0084.2006.00435.x

Blossfeld, H.-P. (2009). Educational Assortative Marriage in Comparative Perspective. Annual Review of Sociology, 35(1), 513-530. https://doi.org/10.1146/annurev-soc-070308-115913

Bobonis, G. J., \& Finan, F. (2009). Neighborhood Peer Effects in Secondary School Enrollment Decisions. Review of Economics and Statistics, 91(4), 695-716. https://doi.org/10.1162/rest.91.4.695

Bossert, W., D'ambrosio, C., \& Peragine, V. (2007). Deprivation and Social Exclusion. Economica, 74(296), 777-803. https://doi.org/10.1111/j.1468-0335.2006.00572.x

Bryan, M. L., \& Jenkins, S. P. (2016). Multilevel Modelling of Country Effects: A Cautionary Tale. European Sociological Review, 32(1), 3-22. https://doi.org/10.1093/esr/jcv059

Cameron, A. C., Gelbach, J. B., \& Miller, D. L. (2008). Bootstrap-Based Improvements for Inference with Clustered Errors. The Review of Economics and Statistics, 90(3), 414-427. Retrieved from http://www.mitpressjournals.org/doi/pdf/10.1162/rest.90.3.414

Cameron, S. V., \& Heckman, J. J. (2001). The Dynamics of Educational Attainment for Black, Hispanic, and White Males. The Journal of Political Economy. Retrieved from http://papers.ssrn.com/abstract=268032

Checchi, D. (2003). Inequality in Incomes and Access to Education: A Cross-Country Analysis (1960-95). Labour, 17(2), 153-201. https://doi.org/10.1111/1467-9914.00226

Chiu, W. H. (1998). Income Inequality, Human Capital Accumulation and Economic Performance. The Economic Journal, 108(446), 44-59. https://doi.org/10.1111/1468-0297.00272

CONEVAL. (2013). CONEVAL. Retrieved from http://www.coneval.gob.mx/Medicion/Paginas/Cohesion\%7B_\%7DSocial.aspx

Connelly, R., \& Zheng, Z. (2003). Determinants of school enrollment and completion of 10 to 18 year olds in China. Economics of Education Review, 22(4), 379-388. https://doi.org/10.1016/S0272-7757(02)000584

Crane, J. (1991). The Epidemic Theory of Ghettos and Neighborhood Effects on Dropping Out and Teenage Childbearing. American Journal of Sociology, 96(5), 1226. https://doi.org/10.1086/229654

Cunha, F., \& Heckman, J. (2007). The Technology of Skill Formation. American Economic Review, 97(2), 31-47. https://doi.org/10.1257/aer.97.2.31

Davis-Kean, P. E. (2005). The influence of parent education and family income on child achievement: the indirect role of parental expectations and the home environment. Journal of Family Psychology: JFP : Journal of the Division of Family Psychology of the American Psychological Association (Division 43), 19(2), 294-304. https://doi.org/10.1037/0893-3200.19.2.294

De Carvalho Filho, I. E. (2012). Household Income as a Determinant of Child Labor and School Enrollment in Brazil : Evidence from a Social Security Reform. Economic Development and Cultural Change, 60(2), 399-435.

de Vries, R., Gosling, S., \& Potter, J. (2011). Income inequality and personality: are less equal U.S. states less agreeable? Social Science and Medicine, 72(12), 1978-85.

https://doi.org/10.1016/j.socscimed.2011.03.046

Debowicz, D., \& Golan, J. (2014). The impact of Oportunidades on human capital and income distribution in 
Mexico: a top-down/bottom-up approach. Journal of Policy Modeling, 36(1), 24-42.

Dincer, O. C. (2011). Trust and schooling in the United States. Economics of Education Review, 30(5), 10971102. https://doi.org/10.1016/j.econedurev.2011.05.014

Dostie, B., \& Jayaraman, R. R. (2006). Determinants of School Enrollment in Indian Villages. Economic Development and Cultural Change, 54(2), 405-421. https://doi.org/10.1086/497006

Edwards, A. C., \& Ureta, M. (2003). International migration, remittances, and schooling: evidence from El Salvador. Journal of Development Economics, 72(2), 429-461. https://doi.org/10.1016/S03043878(03)00115-9

Elgar, F. J., \& Aitken, N. (2011). Income inequality, trust and homicide in 33 countries. European Journal of Public Health, 21(2), 241-6. https://doi.org/10.1093/eurpub/ckq068

Epple, D., \& Romano, R. E. (1996). Ends against the middle: Determining public service provision when there are private alternatives. Journal of Public Economics, 62(3), 297-325. https://doi.org/10.1016/0047-2727(95)01540-X

Filmer, D., \& Pritchett, H. (1999). The Effect of Household Wealth on Educational Attainment : Evidence from 35 Countries. Population and Development Review, 25(1), 85-120.

Galor, O., \& Zeira, J. (1993). Income Distribution and Macroeconomics. The Review of Economic Studies, $60(1), 35-52$.

García-Peñalosa, C. (1995). The Paradox of Education or the Good Side of Inequality. Oxford Economic Papers, 47(2), 265-285.

Gelman, A., \& Hill, J. (2009). Data Analysis. Using Regression and Multilevel/Hierarchical Models. USA: Cambridge University Press.

Gravelle, H., \& Sutton, M. (2009). Income, relative income, and self-reported health in Britain 1979-2000. Health Economics, 18(2), 125-45. https://doi.org/10.1002/hec.1354

Greene, W. (2010). Testing Hypothesis about interaction terms in nonlinear models. Economics Letters, 107(2), 291-296.

Grolnick, W. S., \& Slowiaczek, M. L. (1994). Parents' involvement in children's schooling: a multidimensional conceptualization and motivational model. Child Development, 65(1), 237-52.

Retrieved from http://www.ncbi.nlm.nih.gov/pubmed/8131650

Gumus, S. (2014). The effects of community factors on school participation in Turkey: A multilevel analysis. International Review of Education, 60(1), 79-98. https://doi.org/10.1007/s11159-014-9411-7

Gutiérrez, C., \& Tanaka, R. (2009). Inequality and education decisions in developing countries. The Journal of Economic Inequality, 7(1), 55-81. https://doi.org/10.1007/s10888-008-9095-y

Gutiérrez, R. G., Carter, S., \& Drukker, D. M. (2001). On boundary-value likelihood-ratio tests. In Stata Technical Bulletin Reprints (10th ed.). College Stations, Texas: Stata Press.

Hackman, D. A., Farah, M. J., \& Meaney, M. J. (2010). Socioeconomic status and the brain: mechanistic insights from human and animal research. Nature Reviews. Neuroscience, 11(9), 651-659. https://doi.org/10.1038/nrn2897

Halpern-Manners, A. (2011). The Effect of Family Member Migration on Education and Work Among Nonmigrant Youth in Mexico. Demography, 48(1), 73-99. https://doi.org/10.1007/s13524-010-0010-3

Handa, S. (2002). Raising primary school enrolment in developing countries: The relative importance of supply and demand. Journal of Development Economics, 69(1), 103-128. Retrieved from http://ideas.repec.org/a/eee/deveco/v69y2002i1p103-128.html

Hornby, G., \& Lafaele, R. (2011). Barriers to parental involvement in education: an explanatory model.

Educational Review, 63(1), 37-52. https://doi.org/10.1080/00131911.2010.488049

Iniguez-Montiel, A. J. (2014). Growth with Equity for the Development of Mexico: Poverty, Inequality, and Economic Growth (1992-2008). World Development, 59, 313-326.

https://doi.org/10.1016/j.worlddev.2014.01.011

Jencks, C., \& Mayer, S. E. (1990). The social consequences of growing up in a poor neighborhood. In L. E. Lynn \& M. G.H. (Eds.), Inner-city poverty in the United States (pp. 111-186). Washington, DC: National Academy Press.

Kanbur, R., \& Stiglitz, J. E. (2016). Dynastic inequality, mobility and equality of opportunity. The Journal of Economic Inequality, 14(4), 419-434. https://doi.org/10.1007/s10888-016-9328-4

Kass, R. E., \& Raftery, A. E. (1995). Bayes Factors. Journal of the American Statistical Association, 
90(430), 773-795. Retrieved from

http://amstat.tandfonline.com/doi/abs/10.1080/01621459.1995.10476572

Kearney, M., \& Levine, P. (2016). Income Inequality, Social Mobility, and the Decision to Dropout of High

School. Brookings Papers on Economic ACtivity.

Kling, J. R., Liebman, J. B., \& Katz, L. F. (2007). Experimental Analysis of Neighborhood Effects.

Econometrica, 75(1), 83-119. https://doi.org/10.1111/j.1468-0262.2007.00733.x

Knack, S., \& Keefer, P. (1997). Does Social Capital Have an Economic Payoff? A Cross-Country

Investigation. The Quarterly Journal of Economics, 112(4), 1251-1288.

https://doi.org/10.2307/2951271

Kolenikov, S., \& Angeles, G. (2009). Proxy Variables: Is Principal Components Analysis a Reliable Answer? Review of Income and Wealth, 55(1), 128-165.

Lalive, R., \& Cattaneo, M. A. (2009). Social Interactions and Schooling Decisions. Review of Economics and Statistics, 91(3), 457-477. https://doi.org/10.1162/rest.91.3.457

Lincove, J. A. (2015). Improving Identification of Demand-Side Obstacles to Schooling: Findings from

Revealed and Stated Preference Models in Two SSA Countries. World Development, 66, 69-83.

https://doi.org/10.1016/j.worlddev.2014.07.018

López-Córdova, E. (2005). Globalization, Migration, and Development: The Role of Mexican Migrant Remittances. Economía, 6(1), 217-256.

Loughnan, S., Kuppens, P., Allik, J., Balazs, K., de Lemus, S., Dumont, K., ... Haslam, N. (2011). Economic Inequality Is Linked to Biased Self-Perception. Psychological Science, 22(10), 1254-1258. https://doi.org/10.1177/0956797611417003

Luttmer, E. F. P. (2005). Neighbors as Negatives: Relative Earnings and Well-Being. The Quarterly Journal of Economics, 120(3), 963-1002. https://doi.org/10.1093/qje/120.3.963

Massey, D. S., \& Espinosa, K. E. (1997). What's Driving Mexico-U. S. Migration? A Theoretical, Empirical, and Policy Analysis. American Journal of Sociology, 102(4), 939-999.

Mayer, S. E. S. E. E. (2001). How Did the Increase in Economic Inequality between 1970 and 1990 Affect Children's Educational Attainment? American Journal of Sociology, 107(1), 1-32. https://doi.org/10.1086/323149

Mckenzie, D., \& Rapoport, H. (2011). Can migration reduce educational attainment ? Evidence from Mexico. Journal of Population Economics2, 24(4), 1331-1358.

McLoyd, V. C. (1990). The impact of economic hardship on black families and children: psychological distress, parenting, and socioemotional development. Child Development, 61(2), 311-46. Retrieved from http://www.ncbi.nlm.nih.gov/pubmed/2188806

McWayne, C. M., \& Melzi, G. (2014). Validation of a culture-contextualized measure of family engagement in the early learning of low-income Latino children. Journal of Family Psychology, 28(2), 260.

Milanović, B. (2016). Global inequality : a new approach for the age of globalization. Harvard University Press.

Moulton, B. R. (1986). Random group effects and the precision of regression estimates. Journal of Econometrics, 32(3), 385-397. https://doi.org/10.1016/0304-4076(86)90021-7

Moulton, B. R. (1990). An Illustration of a Pitfall in Estimating the Effects of Aggregate Variables on Micro Units. The Review of Economics and Statistics, 72(2), 334-338. https://doi.org/10.2307/2109724

Neves, P. C., Afonso, Ó., \& Silva, S. T. (2016). A Meta-Analytic Reassessment of the Effects of Inequality on Growth. World Development, 78, 386-400. https://doi.org/10.1016/j.worlddev.2015.10.038

Neville, L. (2012). Do economic equality and generalized trust inhibit academic dishonesty? Evidence from state-level search-engine queries. Psychological Science, 23(4), 339-45. https://doi.org/10.1177/0956797611435980

Nielsen, H. S., \& Svarer, M. (2009). Educational Homogamy: How Much is Opportunities? J. Human Resources, 44(4), 1066-1086. Retrieved from http://jhr.uwpress.org/content/44/4/1066.refs

OECD. (2016a). Inequality Update 2016: Income inequality remains high in the face of weak recovery. Paris. Retrieved from https://www.oecd.org/social/OECD2016-Income-Inequality-Update.pdf

OECD. (2016b). OECD Regions at a Glance 2016. OECD Publishing. https://doi.org/10.1787/reg_glance2016-en

Perotti, R. (1993). Political Equilibrium, Income Distribution, and Growth. The Review of Economic Studies, 
60(4), 755-776. https://doi.org/10.2307/2298098

Peugh, J. L. (2010). A practical guide to multilevel modeling. Journal of School Psychology, 48(1), 85-112. https://doi.org/10.1016/j.jsp.2009.09.002

Piff, P. K. (2014). Wealth and the inflated self: class, entitlement, and narcissism. Personality \& Social Psychology Bulletin, 40(1), 34-43. https://doi.org/10.1177/0146167213501699

Piff, P. K., Stancato, D. M., Côté, S., Mendoza-Denton, R., \& Keltner, D. (2012). Higher social class predicts increased unethical behavior. Proceedings of the National Academy of Sciences of the United States of America, 109(11), 4086-4091. https://doi.org/10.1073/pnas.1118373109

Piketty, T. (2014). Capital in the twenty-first century. Cambridge: Harvard University Press.

Piketty, T. (2015). Putting Distribution Back at the Center of Economics: Reflections on Capital in the Twenty-First Century. Journal of Economic Perspectives, 29(1), 67-88. https://doi.org/10.1257/jep.29.1.67

Ray, R. (2000). Analysis of child labour in Peru and Pakistan: A comparative study. Journal of Population Economics, 13(1), 3-19. https://doi.org/10.1007/s001480050119

Reid, A. (1998). The value of education. Journal of Philosophy of Education1, 32(3), 319-331.

Reiter, J. P., \& Raghunathan, T. E. (2007). The Multiple Adaptations of Multiple Imputation. Journal of the American Statistical Association, 102(January 2013), 1462-1471.

https://doi.org/10.1198/016214507000000932

Rocha, M. G. de la, \& Latapí, A. E. (2016). Indigenous Girls in Rural Mexico: A Success Story? Girlhood Studies, 9(2), 65-81. https://doi.org/10.3167/ghs.2016.090206

Saez, E., \& Zucman, G. (2016). Wealth Inequality in the United States since 1913: Evidence from

Capitalized Income Tax Data. The Quaterly Journal of Economics, 131(2), 519-578.

https://doi.org/10.1093/qje/qjw004

Santibañez, L., Vernez, G., \& Razquin, P. (2005). Education in Mexico Challenges and Opportunities.

Saraví, G., Abrantes, P., \& Bertely-Busquets, M. (2014). Rights and Indigenous Adolescence in Mexico,

New Subjects, New Dilemmas. The International Journal of Children's Rights, 22(2), 313-338.

Scott, M. A., Simonoff, J. S., \& Marx, B. D. (2013). The SAGE Handbook of Multilevel Modeling. (M. A.

Scott, J. S. Simonoff, \& B. D. Marx, Eds.) (First). London: SAGE publications Ltd.

Sen, A. (1983). Poor, Relatively Speaking. Oxford Economic Papers, 35(2), 153-69. Retrieved from http://econpapers.repec.org/RePEc:oup:oxecpp:v:35:y:1983:i:2:p:153-69

SEP. (2012). Encuesta Nacional de Deserción. Retrieved from

http://www.sems.gob.mx/work/models/sems/Resource/10787/1/images/Anexo_6Reporte_de_la_ENDE MS.pdf.

Stiglitz, J. E. (2012). The price of inequality: How today's divided society endangers our future. New York: WW Norton \& Company.

Strulik, H. (2013). School Attendance and Child Labour - A Model of Collective Behaviour. Journal of the European Economic Association, 11(2), 246-277. https://doi.org/10.1111/jeea.12008

Takata, T. (2003). Self-Enhancement and Self-Criticism in Japanese Culture: An Experimental Analysis. Journal of Cross-Cultural Psychology, 34(5), 542-551. https://doi.org/10.1177/0022022103256477

Tanaka, R. (2003). Inequality as a determinant of child labor. Economic Letters, 80, 93-97.

Topel, R. H. (1997). Factor Proportions and Relative Wages: The Supply-Side Determinants of Wage Inequality. Journal of Economic Perspectives, 11(2), 55-74. https://doi.org/10.1257/jep.11.2.55

Trautmann, S. T., van de Kuilen, G., \& Zeckhauser, R. J. (2013). Social Class and (Un)Ethical Behavior: A Framework, With Evidence From a Large Population Sample. Perspectives on Psychological Science, 8(5), 487-497. https://doi.org/10.1177/1745691613491272

UNESCO. (2007). Urban and rural disparities in Latin America: their implications for education access. Buenos Aires.

Uslaner, E. M. (2005). Inequality, Trust, and Civic Engagement. American Politics Research, 33(6), 868894. https://doi.org/10.1177/1532673X04271903

Valentine, N., Verdes-Tennant, E., \& Bonsel, G. (2015). Health systems' responsiveness and reporting behaviour: Multilevel analysis of the influence of individual-level factors in 64 countries. Social Science and Medicine, 138, 152-160. https://doi.org/10.1016/j.socscimed.2015.04.022

Vu, L. T. H., Le, L. C., \& Muhajarine, N. (2013). Multilevel Determinants of Colleges/Universities 
Enrolment in Vietnam: Evidences from the 15\% Sample Data of Population Census 2009. Social Indicators Research, 111(1), 375-386. https://doi.org/10.1007/s11205-012-0011-2

Welch, F. (1999). In Defense of Inequality. The American Economic Review, 89, 1-17. https://doi.org/10.2307/117073

Wilkinson, R., \& Picket, K. E. (2010). The spirit level. Why equality is better for everyone. London: Penguin Books.

Wooldridge, J. M. (2003). Cluster-Sample Methods in Applied Econometrics. The American Economic Review, 93(2), 133-138. https://doi.org/10.2307/3132213 
Table 1. Descriptive statistics

\begin{tabular}{|c|c|c|c|c|c|}
\hline & Observations & $\begin{array}{c}\text { Mean / } \\
\text { Proportion }\end{array}$ & SD & Minimum & Maximum \\
\hline \multicolumn{6}{|c|}{ Dependent Variables } \\
\hline 6-12 year old attendance & $1,461,364$ & 0.959 & 0.199 & 0 & 1 \\
\hline 13-15 year old attendance & 629,079 & 0.822 & 0.382 & 0 & 1 \\
\hline 16-18 year old attendance & 623,667 & 0.489 & 0.499 & 0 & 1 \\
\hline \multicolumn{6}{|c|}{ Individual Level Variables } \\
\hline Female & $2,714,110$ & 0.495 & 0.5 & 0 & 1 \\
\hline Age & $2,714,110$ & 12.011 & 3.737 & 6 & 18 \\
\hline Disability & $2,714,110$ & 0.018 & 0.134 & 0 & 1 \\
\hline Indigenous & $2,714,110$ & 0.211 & 0.408 & 0 & 1 \\
\hline \multicolumn{6}{|c|}{ Household Level Variables } \\
\hline Household wealth & $1,327,350$ & 5.704 & 2.343 & 0 & 11.616 \\
\hline Household Size & $1,327,350$ & 5.264 & 1.984 & 2 & 38 \\
\hline Female $\mathrm{HH}$ head & $1,327,350$ & 0.167 & 0.373 & 0 & 1 \\
\hline $\mathrm{HH}$ head age & $1,327,350$ & 44.299 & 12.614 & 12 & 130 \\
\hline HH Max Ed (years of schooling) & $1,327,350$ & 9.917 & 3.533 & 0 & 24 \\
\hline Social program beneficiary & $1,327,350$ & 0.223 & 0.416 & 0 & 1 \\
\hline \multicolumn{6}{|c|}{ Municipal Level Variables } \\
\hline Municipal Gini & 2,452 & 0.170 & 0.050 & 0.041 & 0.378 \\
\hline Municipal Theil & 2,452 & 0.050 & 0.028 & 0.006 & 0.227 \\
\hline Municipal Atkinson & 2,452 & 0.052 & 0.028 & 0.004 & 0.230 \\
\hline Mean municipal wealth & 2,452 & 5.350 & 1.547 & 1.665 & 9.205 \\
\hline Primary ratio $^{\mathrm{a}}$ & 2,452 & 1.025 & 0.779 & 0.085 & 11.936 \\
\hline Secondary ratio ${ }^{a}$ & 2,452 & 0.170 & 0.144 & 0.001 & 2.512 \\
\hline HighSchool ratio $^{a}$ & 2,452 & 0.087 & 0.102 & 0.000 & 1.765 \\
\hline Schools per child & 2,452 & 0.009 & 0.006 & 0.001 & 0.059 \\
\hline Municipality size & 2,452 & 45,792 & 132,858 & 93 & $1,815,786$ \\
\hline Municipal migration intensity index & 2,452 & 2.700 & 2.311 & 0 & 14.360 \\
\hline
\end{tabular}

Note: Data from INEGI, Consejo Nacional de Población (CONAPO) and Sistema Municipal de Base de Datos

(SIMBAD, which is part of INEGI). The migration variable is an index for outward migration to the United States (see endnote iv for further details).

${ }^{a}$ Ratio of the adult population having completed secondary and high school to those who have not, respectively. 
Table 2. Determinants of individual school enrolment by age range - Multilevel logit models

\begin{tabular}{|c|c|c|c|c|c|c|c|c|c|c|c|c|}
\hline & \multicolumn{4}{|c|}{ 6-12 Year Old } & \multicolumn{4}{|c|}{ 13-15 Year Old } & \multicolumn{4}{|c|}{ 16-18 Year Old } \\
\hline & \multicolumn{2}{|c|}{$\begin{array}{c}\text { (1) } \\
\text { GINI+MEAN+RATIO }\end{array}$} & \multicolumn{2}{|c|}{$\begin{array}{c}(2) \\
\text { GINI+MEAN*RATIO }\end{array}$} & \multicolumn{2}{|c|}{$\begin{array}{c}\text { (3) } \\
\text { GINI+MEAN+RATIO }\end{array}$} & \multicolumn{2}{|c|}{$\begin{array}{c}(4) \\
\text { GINI+MEAN*RATIO }\end{array}$} & \multicolumn{2}{|c|}{$\begin{array}{c}(5) \\
\text { GINI+MEAN+RATIO }\end{array}$} & \multicolumn{2}{|c|}{$\begin{array}{c}(6) \\
\text { GINI+MEAN*RATIO }\end{array}$} \\
\hline & Raw & AME & Raw & AME & Raw & AME & Raw & AME & Raw & AME & Raw & AME \\
\hline HH Wealth & $\begin{array}{r}0.520^{* * *} \\
(0.006)\end{array}$ & $\begin{array}{r}0.008^{* * *} \\
(0.000)\end{array}$ & $\begin{array}{r}0.519^{* * *} \\
(0.006)\end{array}$ & $\begin{array}{r}0.009^{* * *} \\
(0.000)\end{array}$ & $\begin{array}{r}0.359^{* * *} \\
(0.007)\end{array}$ & $\begin{array}{r}0.022^{* * *} \\
(0.000)\end{array}$ & $\begin{array}{r}0.357^{* * *} \\
(0.007)\end{array}$ & $\begin{array}{r}0.022^{* * *} \\
(0.000)\end{array}$ & $\begin{array}{r}0.409^{* * *} \\
(0.007)\end{array}$ & $\begin{array}{r}0.032^{* * *} \\
(0.000)\end{array}$ & $\begin{array}{r}0.408^{* * *} \\
(0.007)\end{array}$ & $\begin{array}{r}0.032^{* * *} \\
(0.000)\end{array}$ \\
\hline HH Max Ed & $\begin{array}{r}0.365^{* * *} \\
(0.003)\end{array}$ & $\begin{array}{r}0.007^{* * *} \\
(0.000)\end{array}$ & $\begin{array}{r}0.363^{* * *} \\
(0.003)\end{array}$ & $\begin{array}{r}0.007^{* * *} \\
(0.000)\end{array}$ & $\begin{array}{r}0.416^{* * *} \\
(0.004)\end{array}$ & $\begin{array}{r}0.037^{* * *} \\
(0.000)\end{array}$ & $\begin{array}{r}0.413^{* * *} \\
(0.004)\end{array}$ & $\begin{array}{r}0.037^{* * *} \\
(0.000)\end{array}$ & $\begin{array}{r}0.504^{* * *} \\
(0.004)\end{array}$ & $\begin{array}{r}0.069^{* * *} \\
(0.000)\end{array}$ & $\begin{array}{r}0.501^{* * *} \\
(0.004)\end{array}$ & $\begin{array}{r}0.069^{* * *} \\
(0.000)\end{array}$ \\
\hline HHWealth*HH Max Ed & $\begin{array}{r}-0.037^{* * *} \\
(0.001)\end{array}$ & & $\begin{array}{r}-0.036^{* * *} \\
(0.001)\end{array}$ & & $\begin{array}{r}-0.020^{* * *} \\
(0.001)\end{array}$ & & $\begin{array}{r}-0.020^{* * *} \\
(0.001)\end{array}$ & & $\begin{array}{r}-0.022^{* * *} \\
(0.001)\end{array}$ & & $\begin{array}{r}-0.022^{* * *} \\
(0.001)\end{array}$ & \\
\hline Mun Gini & $\begin{array}{r}-0.154 \\
(0.341)\end{array}$ & $\begin{array}{r}-0.005 \\
(0.011)\end{array}$ & $\begin{array}{r}-1.607^{* * *} \\
(0.348)\end{array}$ & $\begin{array}{r}-0.053^{* * *} \\
(0.012)\end{array}$ & $\begin{array}{r}-0.256 \\
(0.296)\end{array}$ & $\begin{array}{r}-0.030 \\
(0.035)\end{array}$ & $\begin{array}{r}-2.396^{* * *} \\
(0.313)\end{array}$ & $\begin{array}{r}-0.281^{* * *} \\
(0.037)\end{array}$ & $\begin{array}{r}0.569^{*} \\
(0.260)\end{array}$ & $\begin{array}{r}0.104^{*} \\
(0.047)\end{array}$ & $\begin{array}{r}-2.002^{* * *} \\
(0.286)\end{array}$ & $\begin{array}{r}-0.363^{* * *} \\
(0.052)\end{array}$ \\
\hline Mun Wealth & $\begin{array}{r}-0.279^{* * *} \\
(0.014)\end{array}$ & $\begin{array}{r}-0.009^{* * *} \\
(0.000)\end{array}$ & $\begin{array}{r}-0.272^{* * *} \\
(0.013)\end{array}$ & $\begin{array}{r}-0.014^{* * *} \\
(0.001)\end{array}$ & $\begin{array}{r}-0.291^{* * *} \\
(0.012)\end{array}$ & $\begin{array}{r}-0.034^{* * *} \\
(0.001)\end{array}$ & $\begin{array}{r}-0.314^{* * *} \\
(0.012)\end{array}$ & $\begin{array}{r}-0.054^{* * *} \\
(0.002)\end{array}$ & $\begin{array}{r}-0.232^{* * *} \\
(0.010)\end{array}$ & $\begin{array}{r}-0.042^{* * *} \\
(0.002)\end{array}$ & $\begin{array}{r}-0.295^{* * *} \\
(0.010)\end{array}$ & $\begin{array}{r}-0.080^{* * *} \\
(0.003)\end{array}$ \\
\hline Primary Ratio & $\begin{array}{r}0.198^{* * *} \\
(0.022)\end{array}$ & $\begin{array}{r}0.006^{* * *} \\
(0.001)\end{array}$ & $\begin{array}{r}1.500^{* * *} \\
(0.103)\end{array}$ & $\begin{array}{r}0.023^{* * *} \\
(0.002)\end{array}$ & & & & & & & & \\
\hline MunWealth*Primary Ratio & & & $\begin{array}{r}-0.162^{* * *} \\
(0.013)\end{array}$ & & & & & & & & & \\
\hline Secondary Ratio & & & & & $\begin{array}{r}1.770^{* * *} \\
(0.108)\end{array}$ & $\begin{array}{r}0.207^{* * *} \\
(0.013)\end{array}$ & $\begin{array}{r}8.792^{* * *} \\
(0.448)\end{array}$ & $\begin{array}{r}0.492^{* * *} \\
(0.022)\end{array}$ & & & & \\
\hline MunWealth*Secondary Ratio & & & & & & & $\begin{array}{r}-0.892^{* * *} \\
(0.055)\end{array}$ & & & & & \\
\hline HighSchool Ratio & & & & & & & & & $\begin{array}{r}1.643^{* * *} \\
(0.112)\end{array}$ & $\begin{array}{r}0.299^{* * *} \\
(0.020)\end{array}$ & $\begin{array}{r}12.150^{* * *} \\
(0.613)\end{array}$ & $\begin{array}{r}0.907^{* * *} \\
(0.039)\end{array}$ \\
\hline MunWealth*HighSchool & & & & & & & & & & & $\begin{array}{r}-1.295^{* * *} \\
(0.074)\end{array}$ & \\
\hline Female & $\begin{array}{r}0.025^{* * *} \\
(0.009)\end{array}$ & $\begin{array}{r}0.001^{* * *} \\
(0.000)\end{array}$ & $\begin{array}{r}0.025^{* * *} \\
(0.009)\end{array}$ & $\begin{array}{r}0.001^{* * *} \\
(0.000)\end{array}$ & $\begin{array}{r}0.003 \\
(0.007)\end{array}$ & $\begin{array}{r}0.000 \\
(0.001)\end{array}$ & $\begin{array}{r}0.003 \\
(0.007)\end{array}$ & $\begin{array}{r}0.000 \\
(0.001)\end{array}$ & $\begin{array}{r}0.048^{* * *} \\
(0.006)\end{array}$ & $\begin{array}{r}0.009^{* * *} \\
(0.001)\end{array}$ & $\begin{array}{r}0.048^{* * *} \\
(0.006)\end{array}$ & $\begin{array}{r}0.009^{* * *} \\
(0.001)\end{array}$ \\
\hline Age & $\begin{array}{r}0.039 * * * \\
(0.002)\end{array}$ & $\begin{array}{c}0.001^{* * *} \\
(0.000)\end{array}$ & $\begin{array}{r}0.039^{* * *} \\
(0.002)\end{array}$ & $\begin{array}{r}0.001^{* * *} \\
(0.000)\end{array}$ & $\begin{array}{r}-0.750^{* * *} \\
(0.005)\end{array}$ & $\begin{array}{r}-0.087^{* * * *} \\
(0.001)\end{array}$ & $\begin{array}{r}-0.749^{* * * *} \\
(0.005)\end{array}$ & $\begin{array}{r}-0.088^{* * *} \\
(0.001)\end{array}$ & $\begin{array}{r}-0.664^{* * *} \\
(0.004)\end{array}$ & $\begin{array}{r}-0.121^{* * *} \\
(0.001)\end{array}$ & $\begin{array}{r}-0.664^{* * *} \\
(0.004)\end{array}$ & $\begin{array}{r}-0.120^{* * *} \\
(0.001)\end{array}$ \\
\hline Mental or Physical Disability & $\begin{array}{r}-2.224^{* * *} \\
(0.017)\end{array}$ & $\begin{array}{r}-0.174^{* * *} \\
(0.003)\end{array}$ & $\begin{array}{r}-2.224^{* * *} \\
(0.017)\end{array}$ & $\begin{array}{r}-0.177^{* * *} \\
(0.003)\end{array}$ & $\begin{array}{r}-1.176^{* * *} \\
(0.022)\end{array}$ & $\begin{array}{r}-0.175^{* * *} \\
(0.004)\end{array}$ & $\begin{array}{r}-1.176^{* * *} \\
(0.022)\end{array}$ & $\begin{array}{r}-0.175^{* * *} \\
(0.004)\end{array}$ & $\begin{array}{r}-0.435^{* * *} \\
(0.023)\end{array}$ & $\begin{array}{r}-0.078^{* * *} \\
(0.004)\end{array}$ & $\begin{array}{r}-0.434^{* * *} \\
(0.023)\end{array}$ & $\begin{array}{r}-0.078^{* * *} \\
(0.004)\end{array}$ \\
\hline Indigenous & $\begin{array}{r}-0.074^{* * *} \\
(0.019)\end{array}$ & $\begin{array}{r}-0.002^{* * *} \\
(0.001)\end{array}$ & $\begin{array}{r}-0.051^{* * *} \\
(0.019)\end{array}$ & $\begin{array}{r}-0.002^{* * *} \\
(0.001)\end{array}$ & $\begin{array}{r}0.024 \\
(0.016)\end{array}$ & $\begin{array}{r}0.003 \\
(0.002)\end{array}$ & $\begin{array}{r}0.043^{* * *} \\
(0.016)\end{array}$ & $\begin{array}{r}0.005^{* * *} \\
(0.002)\end{array}$ & $\begin{array}{r}-0.003 \\
(0.014)\end{array}$ & $\begin{array}{r}-0.001 \\
(0.003)\end{array}$ & $\begin{array}{r}0.007 \\
(0.014)\end{array}$ & $\begin{array}{r}0.001 \\
(0.002)\end{array}$ \\
\hline Number of People in $\mathrm{HH}$ & $\begin{array}{r}-0.110^{* * *} \\
(0.002)\end{array}$ & $\begin{array}{r}-0.004^{* * *} \\
(0.000)\end{array}$ & $\begin{array}{r}-0.109^{* * *} \\
(0.002)\end{array}$ & $\begin{array}{r}-0.004^{* * *} \\
(0.000)\end{array}$ & $\begin{array}{r}-0.102^{* * *} \\
(0.002)\end{array}$ & $\begin{array}{r}-0.012^{* * *} \\
(0.000)\end{array}$ & $\begin{array}{r}-0.102^{* * *} \\
(0.002)\end{array}$ & $\begin{array}{r}-0.012^{* * *} \\
(0.000)\end{array}$ & $\begin{array}{r}-0.114^{* * *} \\
(0.001)\end{array}$ & $\begin{array}{r}-0.021^{* * *} \\
(0.000)\end{array}$ & $\begin{array}{r}-0.114^{* * *} \\
(0.001)\end{array}$ & $\begin{array}{r}-0.021^{* * *} \\
(0.000)\end{array}$ \\
\hline Female HH Head & $\begin{array}{r}-0.322^{* * *} \\
(0.013)\end{array}$ & $\begin{array}{r}-0.011^{* * *} \\
(0.001)\end{array}$ & $\begin{array}{r}-0.323^{* * *} \\
(0.013)\end{array}$ & $\begin{array}{r}-0.012^{* * *} \\
(0.001)\end{array}$ & $\begin{array}{r}-0.290^{* * *} \\
(0.010)\end{array}$ & $\begin{array}{r}-0.035^{* * *} \\
(0.001)\end{array}$ & $\begin{array}{r}-0.291^{* * *} \\
(0.010)\end{array}$ & $\begin{array}{r}-0.036^{* * *} \\
(0.001)\end{array}$ & $\begin{array}{r}-0.185^{* * *} \\
(0.008)\end{array}$ & $\begin{array}{r}-0.034^{* * *} \\
(0.001)\end{array}$ & $\begin{array}{r}-0.186^{* * *} \\
(0.008)\end{array}$ & $\begin{array}{r}-0.034^{* * *} \\
(0.001)\end{array}$ \\
\hline HH Head Age & $\begin{array}{r}-0.033^{* * *} \\
(0.002)\end{array}$ & $\begin{array}{r}-0.000^{* * * *} \\
(0.000)\end{array}$ & $\begin{array}{r}-0.033^{* * *} \\
(0.002)\end{array}$ & $\begin{array}{r}-0.000^{* * * *} \\
(0.000)\end{array}$ & $\begin{array}{r}0.014^{* * *} \\
(0.002)\end{array}$ & $\begin{array}{r}-0.000^{* * *} \\
(0.000)\end{array}$ & $\begin{array}{r}0.014^{* * *} \\
(0.002)\end{array}$ & $\begin{array}{r}-0.000^{* * *} \\
(0.000)\end{array}$ & $\begin{array}{r}0.092^{* * *} \\
(0.001)\end{array}$ & $\begin{array}{r}0.003^{* * *} \\
(0.000)\end{array}$ & $\begin{array}{r}0.093^{* * *} \\
(0.001)\end{array}$ & $\begin{array}{r}0.003^{* * *} \\
(0.000)\end{array}$ \\
\hline HH Head Age Squared & $\begin{array}{r}2.20 \mathrm{e}-04^{* * *} \\
(0.000)\end{array}$ & & $\begin{array}{r}2.18 \mathrm{e}-04^{* * *} \\
(0.000)\end{array}$ & & $\begin{array}{r}-1.72 \mathrm{e}-04^{* * *} \\
(0.000)\end{array}$ & & $\begin{array}{r}-1.74 \mathrm{e}-04^{* * *} \\
(0.000)\end{array}$ & & $\begin{array}{r}-8.31 \mathrm{e}-04^{* * *} \\
(0.000)\end{array}$ & & $\begin{array}{r}-8.31 \mathrm{e}-04^{* * *} \\
(0.000)\end{array}$ & \\
\hline Social Program & $\begin{array}{r}0.287^{* * *} \\
(0.011)\end{array}$ & $\begin{array}{r}0.009^{* * *} \\
(0.000)\end{array}$ & $\begin{array}{r}0.288^{* * *} \\
(0.011)\end{array}$ & $\begin{array}{r}0.009^{* * *} \\
(0.000)\end{array}$ & $\begin{array}{r}0.188^{* * *} \\
(0.009)\end{array}$ & $\begin{array}{r}0.021^{* * *} \\
(0.001)\end{array}$ & $\begin{array}{r}0.190^{* * *} \\
(0.009)\end{array}$ & $\begin{array}{r}0.022^{* * *} \\
(0.001)\end{array}$ & $\begin{array}{r}0.117^{* * *} \\
(0.008)\end{array}$ & $\begin{array}{r}0.021^{* * *} \\
(0.001)\end{array}$ & $\begin{array}{r}0.119^{* * *} \\
(0.008)\end{array}$ & $\begin{array}{r}0.021^{* * *} \\
(0.001)\end{array}$ \\
\hline Municipal Schools per Child & $\begin{array}{r}3.039 \\
(2.216)\end{array}$ & $\begin{array}{r}0.097 \\
(0.071)\end{array}$ & $\begin{array}{r}6.387^{* * *} \\
(2.171)\end{array}$ & $\begin{array}{r}0.211^{* * *} \\
(0.072)\end{array}$ & $\begin{array}{r}9.291^{* * *} \\
(1.856)\end{array}$ & $\begin{array}{r}1.084^{* * *} \\
(0.217)\end{array}$ & $\begin{array}{r}12.184^{* * * *} \\
(1.793)\end{array}$ & $\begin{array}{r}1.430^{* * *} \\
(0.211)\end{array}$ & $\begin{array}{r}2.574 \\
(1.594)\end{array}$ & $\begin{array}{r}0.469 \\
(0.290)\end{array}$ & $\begin{array}{r}7.773^{* * *} \\
(1.539)\end{array}$ & $\begin{array}{r}1.410^{* * *} \\
(0.279)\end{array}$ \\
\hline Municipality Size (Pop 1000s) & $\begin{array}{r}-4.00 \mathrm{e}-07^{* * *} \\
(0.000)\end{array}$ & $\begin{array}{r}-0.000^{* * * *} \\
(0.000)\end{array}$ & $\begin{array}{r}-1.68 \mathrm{e}-07^{*} \\
(0.000)\end{array}$ & $\begin{array}{l}-0.000^{*} \\
(0.000)\end{array}$ & $\begin{array}{r}-3.53 \mathrm{e}-07^{* * *} \\
(0.000)\end{array}$ & $\begin{array}{r}-0.000^{* * *} \\
(0.000)\end{array}$ & $\begin{array}{r}-7.17 \mathrm{e}-08 \\
(0.000)\end{array}$ & $\begin{array}{r}-0.000 \\
(0.000)\end{array}$ & $\begin{array}{r}-2.57 \mathrm{e}-07^{* * *} \\
(0.000)\end{array}$ & $\begin{array}{r}-0.000^{* * *} \\
(0.000)\end{array}$ & $\begin{array}{r}-7.46 \mathrm{e}-08 \\
(0.000)\end{array}$ & $\begin{array}{r}-0.000 \\
(0.000)\end{array}$ \\
\hline Municipal Migration Rate & $\begin{array}{r}0.044^{* * *} \\
(0.006)\end{array}$ & $\begin{array}{r}0.001^{* * *} \\
(0.000)\end{array}$ & $\begin{array}{r}0.059^{* * *} \\
(0.005)\end{array}$ & $\begin{array}{r}0.002^{* * *} \\
(0.000)\end{array}$ & $\begin{array}{r}-0.015^{* * *} \\
(0.005)\end{array}$ & $\begin{array}{r}-0.002^{* * *} \\
(0.001)\end{array}$ & $\begin{array}{r}0.001 \\
(0.004)\end{array}$ & $\begin{array}{r}0.000 \\
(0.001)\end{array}$ & $\begin{array}{r}-0.049 * * * \\
(0.004)\end{array}$ & $\begin{array}{r}-0.009^{* * *} \\
(0.001)\end{array}$ & $\begin{array}{r}-0.037^{* * *} \\
(0.004)\end{array}$ & $\begin{array}{r}-0.007^{* * *} \\
(0.001)\end{array}$ \\
\hline Constant & $\begin{array}{r}2.071^{* * *} \\
(0.126) \\
\end{array}$ & & $\begin{array}{r}1.894^{* * *} \\
(0.123) \\
\end{array}$ & & $\begin{array}{r}9.323^{* * *} \\
(0.132) \\
\end{array}$ & & $\begin{array}{r}9.485^{* * *} \\
(0.129) \\
\end{array}$ & & $\begin{array}{r}4.481^{* * *} \\
(0.120) \\
\end{array}$ & & $\begin{array}{r}4.983^{* * *} \\
(0.120) \\
\end{array}$ & \\
\hline Obs. & $1,461,364$ & & $1,461,364$ & & 629,079 & & 629,079 & & 623,667 & & 623,667 & \\
\hline
\end{tabular}




\section{BIC}

Level 2 SD

433,084

0.4348

$-216,400$

432,936

0.4132
$-216,319$

479,634

0.3903
$-239,684$

$5,641.16$

$6,509.74$

0.000

0.000

001 level, respectively.
6,891.64

0.000
479,400

0.3663

$-239,560$

$5,873.84$

0.000
664,685

.03509

$-332,209$

,488.14

0.000
664,412

0.3244

$-332,066$

$6,333.04$ 
Table 3. Robustness check - alternative measures of inequality

\begin{tabular}{|c|c|c|c|c|c|c|}
\hline & \multicolumn{2}{|c|}{ 6-12 Year Old } & \multicolumn{2}{|c|}{ 13-15 Year Old } & \multicolumn{2}{|c|}{$16-18$ Year Old } \\
\hline & $(2 \mathrm{~T})$ & $(2 \mathrm{~A})$ & $(4 \mathrm{~T})$ & $(4 \mathrm{~A})$ & $(6 \mathrm{~T})$ & $(6 \mathrm{~A})$ \\
\hline & Theil & Atkinson & Theil & Atkinson & Theil & Atkinson \\
\hline \multirow[t]{2}{*}{ HH Wealth } & $0.519^{* * *}$ & $0.519^{* * *}$ & $0.357^{* * *}$ & $0.357^{* * *}$ & $0.408^{* * *}$ & $0.408^{* * *}$ \\
\hline & $(0.006)$ & $(0.006)$ & $(0.007)$ & $(0.007)$ & $(0.007)$ & $(0.007)$ \\
\hline \multirow[t]{2}{*}{ HH Max Ed } & $0.362^{* * *}$ & $0.362^{* * *}$ & $0.413^{* * *}$ & $0.413^{* * *}$ & $0.501^{* * *}$ & $0.501^{* * *}$ \\
\hline & $(0.003)$ & $(0.003)$ & $(0.004)$ & $(0.004)$ & $(0.004)$ & $(0.004)$ \\
\hline \multirow{2}{*}{ HHWealth*HH Max Ed } & $-0.036^{* * *}$ & $-0.036^{* * *}$ & $-0.020^{* * *}$ & $-0.020^{* * *}$ & $-0.022^{* * *}$ & $-0.022^{* * *}$ \\
\hline & $(0.001)$ & $(0.001)$ & $(0.001)$ & $(0.001)$ & $(0.001)$ & $(0.001)$ \\
\hline \multirow[t]{2}{*}{ Theil Index } & $-2.687^{* * *}$ & & $-3.395^{* * *}$ & & $-2.392^{* * *}$ & \\
\hline & $(0.535)$ & & $(0.480)$ & & $(0.438)$ & \\
\hline \multirow[t]{2}{*}{ Atkinson Index } & & $-2.744^{* * *}$ & & $-3.373^{* * *}$ & & $-2.365^{* * *}$ \\
\hline & & $(0.519)$ & & $(0.468)$ & & $(0.427)$ \\
\hline \multirow[t]{2}{*}{ Mun Wealth } & $-0.270^{* * *}$ & $-0.266^{* * *}$ & $-0.300^{* * *}$ & $-0.296^{* * *}$ & $-0.276^{* * *}$ & $-0.273^{* * *}$ \\
\hline & $(0.013)$ & $(0.012)$ & $(0.011)$ & $(0.011)$ & $(0.010)$ & $(0.009)$ \\
\hline \multirow[t]{2}{*}{ Primary Ratio } & $1.461^{* * *}$ & $1.480^{* * *}$ & & & & \\
\hline & $(0.100)$ & $(0.100)$ & & & & \\
\hline \multirow[t]{2}{*}{ MunWealth*Primary Ratio } & $-0.157^{* * *}$ & $-0.160^{* * *}$ & & & & \\
\hline & $(0.012)$ & $(0.012)$ & & & & \\
\hline \multirow{2}{*}{ Secondary Ratio } & & & $8.325^{* * *}$ & $8.454^{* * *}$ & & \\
\hline & & & $(0.428)$ & $(0.434)$ & & \\
\hline \multirow[t]{2}{*}{ MunWealth*Secondary Ratio } & & & $-0.833^{* * *}$ & $-0.850^{* * *}$ & & \\
\hline & & & $(0.053)$ & $(0.053)$ & & \\
\hline \multirow[t]{2}{*}{ HighSchool Ratio } & & & & & $11.285^{* * *}$ & $11.405^{* * *}$ \\
\hline & & & & & $(0.581)$ & $(0.590)$ \\
\hline \multirow[t]{2}{*}{ MunWealth*HighSchool } & & & & & $-1.190^{* * *}$ & $-1.205^{* * *}$ \\
\hline & & & & & $(0.071)$ & $(0.072)$ \\
\hline \multirow[t]{2}{*}{ Female } & $0.025^{* * *}$ & $0.025^{* * *}$ & 0.003 & 0.003 & $0.048^{* * *}$ & $0.048^{* * *}$ \\
\hline & $(0.009)$ & $(0.009)$ & $(0.007)$ & $(0.007)$ & $(0.006)$ & $(0.006)$ \\
\hline \multirow[t]{2}{*}{ Age } & $0.039 * * *$ & $0.039^{* * *}$ & $-0.749 * * *$ & $-0.749 * * *$ & $-0.664^{* * *}$ & $-0.664^{* * *}$ \\
\hline & $(0.002)$ & $(0.002)$ & $(0.005)$ & $(0.005)$ & $(0.004)$ & $(0.004)$ \\
\hline \multirow[t]{2}{*}{ Mental or Physical Disability } & $-2.224^{* * *}$ & $-2.224^{* * *}$ & $-1.176^{* * *}$ & $-1.176^{* * *}$ & $-0.435^{* * *}$ & $-0.435^{* * *}$ \\
\hline & $(0.017)$ & $(0.017)$ & $(0.022)$ & $(0.022)$ & $(0.023)$ & $(0.023)$ \\
\hline \multirow[t]{2}{*}{ Indigenous } & $-0.048^{*}$ & $-0.049^{* * *}$ & $0.047^{* * *}$ & $0.046^{* * *}$ & 0.011 & 0.010 \\
\hline & $(0.019)$ & $(0.019)$ & $(0.016)$ & $(0.016)$ & $(0.014)$ & $(0.014)$ \\
\hline \multirow[t]{2}{*}{ Number of People in $\mathrm{HH}$} & $-0.109^{* * *}$ & $-0.109^{* * *}$ & $-0.102^{* * *}$ & $-0.102^{* * *}$ & $-0.114^{* * *}$ & $-0.114^{* * *}$ \\
\hline & $(0.002)$ & $(0.002)$ & $(0.002)$ & $(0.002)$ & $(0.001)$ & $(0.001)$ \\
\hline \multirow[t]{2}{*}{ Female HH Head } & $-0.323^{* * *}$ & $-0.323^{* * *}$ & $-0.291^{* * *}$ & $-0.291 * * *$ & $-0.187^{* * *}$ & $-0.187^{* * *}$ \\
\hline & $(0.013)$ & $(0.013)$ & $(0.010)$ & $(0.010)$ & $(0.008)$ & $(0.008)$ \\
\hline HH Head Age & $-0.033^{* * *}$ & $-0.033^{* * *}$ & $0.014^{* * *}$ & $0.014^{* * *}$ & $0.093^{* * *}$ & $0.093^{* * *}$ \\
\hline & $(0.002)$ & $(0.002)$ & $(0.002)$ & $(0.002)$ & $(0.001)$ & $(0.001)$ \\
\hline HH Head Age Squared & $2.18 \mathrm{e}-04^{* * *}$ & $2.18 \mathrm{e}-04^{* * *}$ & $1.74 \mathrm{e}-04^{* * *}$ & $1.74 \mathrm{e}-04^{* * *}$ & $-8.31 \mathrm{e}-04^{* * *}$ & $-8.31 \mathrm{e}-04^{* * *}$ \\
\hline & $(0.000)$ & $(0.000)$ & $(0.000)$ & $(0.000)$ & $(0.000)$ & $(0.000)$ \\
\hline Social Program & $0.288^{* * *}$ & $0.288^{* * *}$ & $0.190^{* * *}$ & $0.190^{* * *}$ & $0.119^{* * *}$ & $0.119^{* * *}$ \\
\hline & $(0.011)$ & $(0.011)$ & $(0.009)$ & $(0.009)$ & $(0.008)$ & $(0.008)$ \\
\hline Municipal Schools per Child & $6.921^{* * *}$ & $7.199 * * *$ & $12.452^{* * *}$ & $12.713^{* * *}$ & $7.546^{* * *}$ & $7.747^{* * *}$ \\
\hline & $(2.185)$ & $(2.191)$ & $(1.806)$ & $(1.811)$ & $(1.553)$ & $(1.560)$ \\
\hline
\end{tabular}




\begin{tabular}{|c|c|c|c|c|c|c|}
\hline Municipality Size (Pop 1000s) & $\begin{array}{r}-1.61 \mathrm{e}-07^{*} \\
(0.000)\end{array}$ & $\begin{array}{r}-1.63 \mathrm{e}-07^{*} \\
(0.000)\end{array}$ & $\begin{array}{r}-7.02 \mathrm{e}-08 \\
(0.000)\end{array}$ & $\begin{array}{r}-6.99 \mathrm{e}-08 \\
(0.000)\end{array}$ & $\begin{array}{r}-7.56 \mathrm{e}-08 \\
(0.000)\end{array}$ & $\begin{array}{r}-7.43 e-08 \\
(0.000)\end{array}$ \\
\hline \multirow[t]{2}{*}{ Municipal Migration Rate } & $0.058^{* * *}$ & $0.059^{* * *}$ & -0.001 & -0.000 & $-0.038^{* * *}$ & $-0.038^{* * *}$ \\
\hline & $(0.005)$ & $(0.005)$ & $(0.004)$ & $(0.004)$ & $(0.004)$ & $(0.004)$ \\
\hline \multirow{2}{*}{ Constant } & $1.748^{* * *}$ & $1.731^{* * *}$ & $9.198^{* * *}$ & $9.170^{* * *}$ & $4.685^{* * *}$ & $4.667^{* * *}$ \\
\hline & $(0.101)$ & $(0.098)$ & $(0.111)$ & $(0.109)$ & $(0.102)$ & $(0.100)$ \\
\hline Obs. & $1,461,364$ & $1,461,364$ & 629,079 & 629,079 & 623,667 & 623,667 \\
\hline BIC & 432,932 & 432,929 & 479,408 & 479,406 & 664,431 & 664,430 \\
\hline Level 2 SD & 0.4126 & 0.4122 & 0.3667 & 0.3666 & 0.3261 & 0.3260 \\
\hline \multirow{3}{*}{$\begin{array}{l}\text { LL } \\
\text { LR test H0: Logit = Multilevel Logit: } \\
\text { Chi2 } \\
\text { p-value }\end{array}$} & $-216,317$ & $-216,316$ & $-239,564$ & $-239,563$ & $-332,075$ & $-332,075$ \\
\hline & & & & & & \\
\hline & $\begin{array}{r}5,601.37 \\
0.000\end{array}$ & $0.000^{5,616.47}$ & $\int^{5,892.21}$ & $\int^{5,877.43}$ & $0.000^{6,3 \varepsilon}$ & $0.000^{6,365}$ \\
\hline
\end{tabular}


Table 4. Robustness check - subsamples by gender and standard of living

Sample Split by Gender

\begin{tabular}{|c|c|c|c|c|c|c|c|c|c|c|c|c|}
\hline & \multicolumn{8}{|c|}{ Sample Split by Gender } & \multicolumn{4}{|c|}{ Sample Split by Wealth } \\
\hline & \multicolumn{2}{|c|}{ 6-12 Year Olds } & \multicolumn{2}{|c|}{ 13-15 Year Olds } & \multicolumn{2}{|c|}{ 16-18 Year Olds } & \multicolumn{2}{|c|}{ 6-12 Year Olds } & \multicolumn{2}{|c|}{ 13-15 Year Olds } & \multicolumn{2}{|c|}{ 16-18 Year Olds } \\
\hline & $(2 \mathrm{G})$ & $(2 \mathrm{~B})$ & $(4 \mathrm{G})$ & $(4 \mathrm{~B})$ & $(6 \mathrm{G})$ & $(6 \mathrm{~B})$ & $(2 \mathrm{P})$ & $(2 \mathrm{R})$ & $(4 \mathrm{P})$ & $(4 \mathrm{R})$ & $(6 \mathrm{P})$ & $(6 \mathrm{R})$ \\
\hline & Female & Male & Female & Male & Female & Male & Poorer & Richer & Poorer & Richer & Poorer & Richer \\
\hline HH Wealth & $0.525^{* * *}$ & $0.516^{* * *}$ & $0.357^{* * *}$ & $0.364^{* * *}$ & $0.457^{* * *}$ & $0.359^{* * *}$ & $0.574^{* * *}$ & $0.526^{* * *}$ & $0.270^{* * *}$ & $0.609^{* * *}$ & $0.163^{* * *}$ & $0.818^{* * *}$ \\
\hline & $(0.009)$ & $(0.009)$ & $(0.010)$ & $(0.009)$ & $(0.009)$ & $(0.009)$ & $(0.011)$ & $(0.028)$ & $(0.014)$ & $(0.025)$ & $(0.017)$ & $(0.019)$ \\
\hline HH Max Ed & $\begin{array}{r}0.377^{* * *} \\
(0.005)\end{array}$ & $\begin{array}{r}0.353^{* * *} \\
(0.005)\end{array}$ & $\begin{array}{r}0.410^{* * *} \\
(0.006)\end{array}$ & $\begin{array}{r}0.423^{* * *} \\
(0.006)\end{array}$ & $\begin{array}{r}0.530^{* * *} \\
(0.006)\end{array}$ & $\begin{array}{r}0.479 * * * \\
(0.005)\end{array}$ & $\begin{array}{r}0.376^{* * *} \\
(0.005)\end{array}$ & $\begin{array}{r}0.373^{* * *} \\
(0.018)\end{array}$ & $\begin{array}{r}0.406^{* * *} \\
(0.006)\end{array}$ & $\begin{array}{r}0.489 * * * \\
(0.018)\end{array}$ & $\begin{array}{r}0.471^{* * *} \\
(0.007)\end{array}$ & $\begin{array}{r}0.646^{* * *} \\
(0.013)\end{array}$ \\
\hline HHWealth*HH Max Ed & $\begin{array}{r}-0.039 * * * \\
(0.001)\end{array}$ & $\begin{array}{r}-0.034^{* * *} \\
(0.001)\end{array}$ & $\begin{array}{r}-0.020^{* * *} \\
(0.001)\end{array}$ & $\begin{array}{r}-0.021^{* * *} \\
(0.001)\end{array}$ & $\begin{array}{r}-0.027^{* * *} \\
(0.001)\end{array}$ & $\begin{array}{r}-0.017^{* * *} \\
(0.001)\end{array}$ & $\begin{array}{r}-0.041^{* * *} \\
(0.001)\end{array}$ & $\begin{array}{r}-0.037^{* * *} \\
(0.002)\end{array}$ & $\begin{array}{r}-0.014^{* * *} \\
(0.002)\end{array}$ & $\begin{array}{r}-0.034^{* * *} \\
(0.002)\end{array}$ & $\begin{array}{r}-0.007^{* * *} \\
(0.002)\end{array}$ & $\begin{array}{r}-0.045^{* * *} \\
(0.002)\end{array}$ \\
\hline Mun Gini & $\begin{array}{r}-1.515^{* * * *} \\
(0.408)\end{array}$ & $\begin{array}{r}-1.613^{* * *} \\
(0.383)\end{array}$ & $\begin{array}{r}-2.145^{* * *} \\
(0.357)\end{array}$ & $\begin{array}{r}-2.379^{* * * *} \\
(0.359)\end{array}$ & $\begin{array}{r}-1.806^{* * *} \\
(0.328)\end{array}$ & $\begin{array}{r}-2.051^{* * *} \\
(0.324)\end{array}$ & $\begin{array}{r}-1.433^{* * *} \\
(0.409)\end{array}$ & $\begin{array}{r}-0.993 \\
(0.618)\end{array}$ & $\begin{array}{r}-2.195^{* * * *} \\
(0.353)\end{array}$ & $\begin{array}{r}-2.780^{* * *} \\
(0.527)\end{array}$ & $\begin{array}{r}-2.169^{* * *} \\
(0.344)\end{array}$ & $\begin{array}{r}-2.529^{* * *} \\
(0.386)\end{array}$ \\
\hline Mun Wealth & $\begin{array}{r}-0.248^{* * *} \\
(0.016)\end{array}$ & $\begin{array}{r}-0.279^{* * *} \\
(0.015)\end{array}$ & $\begin{array}{r}-0.272^{* * *} \\
(0.014)\end{array}$ & $\begin{array}{r}-0.346^{* * * *} \\
(0.014)\end{array}$ & $\begin{array}{r}-0.258^{* * *} \\
(0.012)\end{array}$ & $\begin{array}{r}-0.326^{* * *} \\
(0.012)\end{array}$ & $\begin{array}{r}-0.285^{* * *} \\
(0.016)\end{array}$ & $\begin{array}{r}-0.174^{* * *} \\
(0.028)\end{array}$ & $\begin{array}{r}-0.313^{* * * *} \\
(0.014)\end{array}$ & $\begin{array}{r}-0.299^{* * *} \\
(0.023)\end{array}$ & $\begin{array}{r}-0.271^{* * *} \\
(0.012)\end{array}$ & $\begin{array}{r}-0.306^{* * *} \\
(0.017)\end{array}$ \\
\hline Primary Ratio & $\begin{array}{r}1.578^{* * *} \\
(0.121)\end{array}$ & $\begin{array}{r}1.459^{* * *} \\
(0.113)\end{array}$ & & & & & $\begin{array}{r}1.712^{* * *} \\
(0.133)\end{array}$ & $\begin{array}{r}1.056^{* * *} \\
(0.139)\end{array}$ & & & & \\
\hline MunWealth*Primary Ratio & $\begin{array}{r}-0.171^{* * *} \\
(0.015)\end{array}$ & $\begin{array}{r}-0.158^{* * *} \\
(0.014)\end{array}$ & & & & & $\begin{array}{r}-0.182^{* * *} \\
(0.017)\end{array}$ & $\begin{array}{r}-0.116^{* * *} \\
(0.016)\end{array}$ & & & & \\
\hline Secondary Ratio & & & $\begin{array}{r}9.396^{* * *} \\
(0.524)\end{array}$ & $\begin{array}{r}8.241^{* * *} \\
(0.516)\end{array}$ & & & & & $\begin{array}{r}8.968^{* * *} \\
(0.554)\end{array}$ & $\begin{array}{r}9.324^{* * *} \\
(0.626)\end{array}$ & & \\
\hline MunWealth*Secondary Ratio & & & $\begin{array}{r}-0.947^{* * *} \\
(0.065)\end{array}$ & $\begin{array}{r}-0.837^{* * *} \\
(0.063)\end{array}$ & & & & & $\begin{array}{r}-0.900^{* * *} \\
(0.075)\end{array}$ & $\begin{array}{r}-0.967^{* * *} \\
(0.074)\end{array}$ & & \\
\hline HighSchool Ratio & & & & & $\begin{array}{r}12.046^{* * *} \\
(0.693)\end{array}$ & $\begin{array}{r}11.865^{* * *} \\
(0.688)\end{array}$ & & & & & $\begin{array}{r}13.592^{* * *} \\
(0.835)\end{array}$ & $\begin{array}{r}11.568^{* * *} \\
(0.654)\end{array}$ \\
\hline MunWealth*HighSchool & & & & & $\begin{array}{r}-1.296^{* * *} \\
(0.084)\end{array}$ & $\begin{array}{r}-1.246^{* * *} \\
(0.083)\end{array}$ & & & & & $\begin{array}{r}-1.490^{* * *} \\
(0.110)\end{array}$ & $\begin{array}{r}-1.246^{* * *} \\
(0.078)\end{array}$ \\
\hline Female & & & & & & & $\begin{array}{r}0.015 \\
(0.010)\end{array}$ & $\begin{array}{r}0.062^{* * *} \\
(0.018)\end{array}$ & $\begin{array}{r}-0.082^{* * *} \\
(0.009)\end{array}$ & $\begin{array}{r}0.186^{* * *} \\
(0.013)\end{array}$ & $\begin{array}{l}-0.019^{*} \\
(0.008)\end{array}$ & $\begin{array}{r}0.128^{* * *} \\
(0.009)\end{array}$ \\
\hline Age & $\begin{array}{r}0.037^{* * *} \\
(0.003)\end{array}$ & $\begin{array}{r}0.040^{* * *} \\
(0.003)\end{array}$ & $\begin{array}{r}-0.750^{* * *} \\
(0.007)\end{array}$ & $\begin{array}{r}-0.753^{* * *} \\
(0.007)\end{array}$ & $\begin{array}{r}-0.674^{* * *} \\
(0.006)\end{array}$ & $\begin{array}{r}-0.655^{* * *} \\
(0.005)\end{array}$ & $\begin{array}{r}0.060^{* * *} \\
(0.003)\end{array}$ & $\begin{array}{r}-0.021^{* * *} \\
(0.004)\end{array}$ & $\begin{array}{r}-0.763^{* * *} \\
(0.006)\end{array}$ & $\begin{array}{r}-0.727^{* * *} \\
(0.009)\end{array}$ & $\begin{array}{r}-0.727^{* * *} \\
(0.005)\end{array}$ & $\begin{array}{r}-0.602^{* * *} \\
(0.006)\end{array}$ \\
\hline Mental or Physical Disability & $\begin{array}{r}-2.302^{* * * *} \\
(0.026)\end{array}$ & $\begin{array}{r}-2.156^{* * *} \\
(0.023)\end{array}$ & $\begin{array}{r}-1.151^{* * *} \\
(0.034)\end{array}$ & $\begin{array}{r}-1.192^{* * * *} \\
(0.030)\end{array}$ & $\begin{array}{r}-0.409^{* * *} \\
(0.035)\end{array}$ & $\begin{array}{r}-0.460^{* * *} \\
(0.032)\end{array}$ & $\begin{array}{r}-2.293^{* * *} \\
(0.021)\end{array}$ & $\begin{array}{r}-2.122^{* * *} \\
(0.028)\end{array}$ & $\begin{array}{r}-1.080^{* * * *} \\
(0.029)\end{array}$ & $\begin{array}{r}-1.312^{* * *} \\
(0.035)\end{array}$ & $\begin{array}{r}-0.315^{* * *} \\
(0.033)\end{array}$ & $\begin{array}{r}-0.542^{* * *} \\
(0.033)\end{array}$ \\
\hline Indigenous & $\begin{array}{r}-0.085^{* * *} \\
(0.026)\end{array}$ & $\begin{array}{r}0.007 \\
(0.025)\end{array}$ & $\begin{array}{r}-0.027 \\
(0.021)\end{array}$ & $\begin{array}{r}0.160^{* * * *} \\
(0.022)\end{array}$ & $\begin{array}{r}-0.108^{* * *} \\
(0.019)\end{array}$ & $\begin{array}{r}0.141^{* * *} \\
(0.019)\end{array}$ & $\begin{array}{l}-0.046^{*} \\
(0.020)\end{array}$ & $\begin{array}{r}-0.334^{* * *} \\
(0.078)\end{array}$ & $\begin{array}{r}0.045^{* * *} \\
(0.017)\end{array}$ & $\begin{array}{r}-0.353^{* * *} \\
(0.051)\end{array}$ & $\begin{array}{r}-0.001 \\
(0.015)\end{array}$ & $\begin{array}{r}-0.404^{* * *} \\
(0.034)\end{array}$ \\
\hline Number of People in $\mathrm{HH}$ & $\begin{array}{r}-0.110^{* * *} \\
(0.003)\end{array}$ & $\begin{array}{r}-0.110^{* * *} \\
(0.002)\end{array}$ & $\begin{array}{r}-0.102^{* * *} \\
(0.002)\end{array}$ & $\begin{array}{r}-0.103^{* * *} \\
(0.002)\end{array}$ & $\begin{array}{r}-0.121^{* * *} \\
(0.002)\end{array}$ & $\begin{array}{r}-0.116^{* * *} \\
(0.002)\end{array}$ & $\begin{array}{r}-0.116^{* * *} \\
(0.002)\end{array}$ & $\begin{array}{r}-0.095^{* * *} \\
(0.004)\end{array}$ & $\begin{array}{r}-0.089 * * * \\
(0.002)\end{array}$ & $\begin{array}{r}-0.135^{* * *} \\
(0.003)\end{array}$ & $\begin{array}{r}-0.083^{* * *} \\
(0.002)\end{array}$ & $\begin{array}{r}-0.164^{* * *} \\
(0.002)\end{array}$ \\
\hline Female HH Head & $\begin{array}{r}-0.259^{* * *} \\
(0.019)\end{array}$ & $\begin{array}{r}-0.386^{* * *} \\
(0.017)\end{array}$ & $\begin{array}{r}-0.231^{* * *} \\
(0.015)\end{array}$ & $\begin{array}{r}-0.352^{* * *} \\
(0.014)\end{array}$ & $\begin{array}{r}-0.128^{* * *} \\
(0.012)\end{array}$ & $\begin{array}{r}-0.254^{* * *} \\
(0.012)\end{array}$ & $\begin{array}{r}-0.370^{* * *} \\
(0.016)\end{array}$ & $\begin{array}{r}-0.257^{* * *} \\
(0.022)\end{array}$ & $\begin{array}{r}-0.285^{* * *} \\
(0.013)\end{array}$ & $\begin{array}{r}-0.296^{* * *} \\
(0.017)\end{array}$ & $\begin{array}{r}-0.159^{* * *} \\
(0.012)\end{array}$ & $\begin{array}{r}-0.200^{* * *} \\
(0.011)\end{array}$ \\
\hline HH Head Age & $\begin{array}{r}-0.027^{* * *} \\
(0.003)\end{array}$ & $\begin{array}{r}-0.038^{* * *} \\
(0.003)\end{array}$ & $\begin{array}{r}0.032^{* * *} \\
(0.003)\end{array}$ & $\begin{array}{l}-0.005^{*} \\
(0.003)\end{array}$ & $\begin{array}{r}0.128^{* * *} \\
(0.002)\end{array}$ & $\begin{array}{r}0.039^{* * *} \\
(0.002)\end{array}$ & $\begin{array}{r}-0.044^{* * *} \\
(0.002)\end{array}$ & $\begin{array}{r}0.001 \\
(0.004)\end{array}$ & $\begin{array}{r}0.011^{* * *} \\
(0.002)\end{array}$ & $\begin{array}{r}0.020^{* * *} \\
(0.004)\end{array}$ & $\begin{array}{r}0.099 * * * \\
(0.002)\end{array}$ & $\begin{array}{r}0.081^{* * *} \\
(0.002)\end{array}$ \\
\hline HH Head Age Squared & $\begin{array}{r}1.54 \mathrm{e}- \\
04^{* * *} \\
(0.000)\end{array}$ & $\begin{array}{r}2.59 \mathrm{e}- \\
04^{* * *} \\
(0.000)\end{array}$ & $\begin{array}{r}-3.25 \mathrm{e}- \\
04^{* * *} \\
(0.000)\end{array}$ & $\begin{array}{r}1.21 \mathrm{e}-05 \\
(0.000)\end{array}$ & $\begin{array}{r}-1.13 \mathrm{e}- \\
03^{* * *} \\
(0.000)\end{array}$ & $\begin{array}{r}-3.46 \mathrm{e}- \\
04^{* * *} \\
(0.000)\end{array}$ & $\begin{array}{r}3.00 \mathrm{e}- \\
04^{* * *} \\
(0.000)\end{array}$ & $\begin{array}{r}-5.64 \mathrm{e}-05 \\
(0.000)\end{array}$ & $\begin{array}{r}-1.56 \mathrm{e}- \\
04^{* * *} \\
(0.000)\end{array}$ & $\begin{array}{r}-1.96 \mathrm{e}- \\
04 * * * \\
(0.000)\end{array}$ & $\begin{array}{r}-9.02 \mathrm{e}- \\
04^{* * *} \\
(0.000)\end{array}$ & $\begin{array}{r}-7.05 \mathrm{e}- \\
04^{* * *} \\
(0.000)\end{array}$ \\
\hline Social Program & $\begin{array}{r}0.290^{* * *} \\
(0.016)\end{array}$ & $\begin{array}{r}0.288^{* * *} \\
(0.016)\end{array}$ & $\begin{array}{r}0.206^{* * *} \\
(0.013)\end{array}$ & $\begin{array}{r}0.173^{* * *} \\
(0.013)\end{array}$ & $\begin{array}{r}0.156^{* * *} \\
(0.011)\end{array}$ & $\begin{array}{r}0.065^{* * *} \\
(0.011)\end{array}$ & $\begin{array}{r}0.329^{* * *} \\
(0.013)\end{array}$ & $\begin{array}{r}0.154^{* * * *} \\
(0.030)\end{array}$ & $\begin{array}{r}0.187^{* * *} \\
(0.010)\end{array}$ & $\begin{array}{r}0.233^{* * *} \\
(0.020)\end{array}$ & $\begin{array}{r}0.079^{* * *} \\
(0.010)\end{array}$ & $\begin{array}{r}0.207^{* * *} \\
(0.014)\end{array}$ \\
\hline Municipal Schools per Child & $6.433^{*}$ & $7.150^{* * *}$ & $14.030^{* * *}$ & $9.798^{* * *}$ & $10.927^{* * *}$ & $5.771^{* * *}$ & $7.424^{* * *}$ & 3.916 & $9.338 * * *$ & $19.895^{* * *}$ & $4.968^{* * *}$ & $11.167^{* * *}$ \\
\hline
\end{tabular}




\begin{tabular}{|c|c|c|c|c|c|c|c|c|c|c|c|c|}
\hline & $(2.658)$ & $(2.495)$ & $(2.120)$ & $(2.093)$ & $(1.817)$ & $(1.787)$ & $(2.534)$ & $(3.473)$ & $(2.027)$ & $(2.686)$ & $(1.861)$ & $(1.875)$ \\
\hline \multirow[t]{2}{*}{$\begin{array}{l}\text { Municipality Size (Pop } \\
\text { 1000s) }\end{array}$} & $-2.29 \mathrm{e}-08$ & $-3.53 e-08$ & $-2.11 \mathrm{e}-08$ & $\begin{array}{r}1.01 \mathrm{e}^{-} \\
07^{* * *}\end{array}$ & $2.07 e-08$ & $4.10 \mathrm{e}-08$ & $\begin{array}{r}-2.21 \mathrm{e}^{-} \\
07^{* *}\end{array}$ & $\begin{array}{r}-1.94 \mathrm{e}^{-} \\
07^{* * *}\end{array}$ & $-1.52 \mathrm{e}-07^{*}$ & $-7.08 \mathrm{e}-08$ & $-1.14 \mathrm{e}-07$ & $-8.62 \mathrm{e}-08^{*}$ \\
\hline & $(0.000)$ & $(0.000)$ & $(0.000)$ & $(0.000)$ & $(0.000)$ & $(0.000)$ & $(0.000)$ & $(0.000)$ & $(0.000)$ & $(0.000)$ & $(0.000)$ & $(0.000)$ \\
\hline Municipal Migration Rate & $\begin{array}{r}0.065^{* * *} \\
(0.007)\end{array}$ & $\begin{array}{r}0.055^{* * *} \\
(0.006)\end{array}$ & $\begin{array}{r}0.005 \\
(0.005)\end{array}$ & $\begin{array}{r}0.000 \\
(0.005)\end{array}$ & $\begin{array}{r}-0.028^{* * *} \\
(0.004)\end{array}$ & $\begin{array}{r}-0.046^{* * *} \\
(0.004)\end{array}$ & $\begin{array}{r}0.068^{* * *} \\
(0.006)\end{array}$ & $\begin{array}{r}0.052^{* * *} \\
(0.008)\end{array}$ & $\begin{array}{r}0.009 * \\
(0.005)\end{array}$ & $\begin{array}{r}-0.007 \\
(0.006)\end{array}$ & $\begin{array}{r}-0.033^{* * *} \\
(0.005)\end{array}$ & $\begin{array}{r}-0.041^{* * *} \\
(0.004)\end{array}$ \\
\hline \multirow[t]{2}{*}{ Constant } & $1.586^{* * *}$ & $2.046^{* * *}$ & $8.716^{* * *}$ & & $3.781^{* * *}$ & $6.656^{* * *}$ & $1.839^{* * *}$ & $0.743^{*}$ & $9.901^{* * *}$ & $7.385^{* * *}$ & $6.317^{* * *}$ & $1.788^{* * *}$ \\
\hline & $(0.151)$ & $(0.143)$ & $(0.163)$ & $\begin{array}{r}10.174^{* * *} \\
(0.165) \\
\end{array}$ & $(0.153)$ & $(0.154)$ & $(0.143)$ & $(0.335)$ & $(0.151)$ & $(0.305)$ & $(0.157)$ & $(0.229)$ \\
\hline Obs. & 720,815 & 740,549 & 311,693 & 317,386 & 309,708 & 313,959 & 823,145 & 638,219 & 350,959 & 278,120 & 333,937 & 289,730 \\
\hline BIC & 210,173 & 223,620 & 235,414 & 243,779 & 327,183 & 335,934 & 307,189 & 125,283 & 317,179 & 161,622 & 352,104 & 309,203 \\
\hline Level 2 SD & 0.4353 & 0.4044 & 0.3752 & 0.3812 & 0.3379 & 0.3358 & 0.4727 & 0.3623 & 0.3962 & 0.3442 & 0.3656 & 0.2691 \\
\hline LL & $-104,952$ & $-111,675$ & $-117,580$ & $-121,763$ & $-163,465$ & $-167,841$ & $-153,452$ & $-62,501$ & $-158,456$ & $-80,679$ & $-175,919$ & $-154,470$ \\
\hline \multicolumn{13}{|c|}{ LR test $\mathrm{H} 0$ : Logit $=$ Multilevel Logit: } \\
\hline Chi2 & $2,656.74$ & $2,177.31$ & $2,684.24$ & $2,670.96$ & $2,954.72$ & $2,972.02$ & $5,022.85$ & 546.68 & $4,426.07$ & $1,044.60$ & $4,244.26$ & $1,571.12$ \\
\hline p-value & 0.000 & 0.000 & 0.000 & 0.000 & 0.000 & 0.000 & 0.000 & 0.000 & 0.000 & 0.000 & 0.000 & 0.000 \\
\hline
\end{tabular}


Figure 1. Municipal school enrolment rates and Gini coefficient

Enrolment Rates

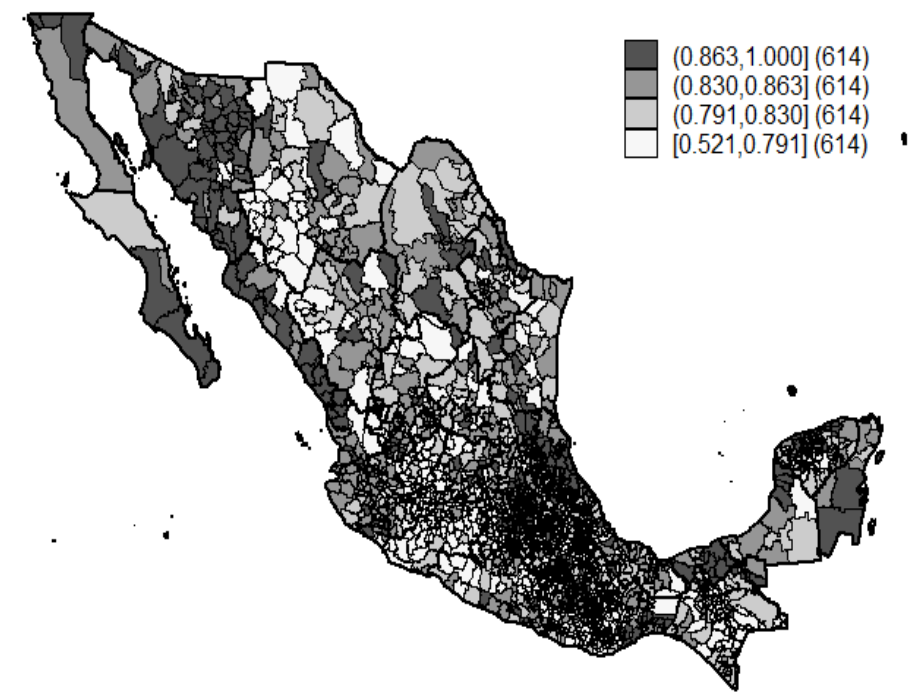

Gini Coefficient

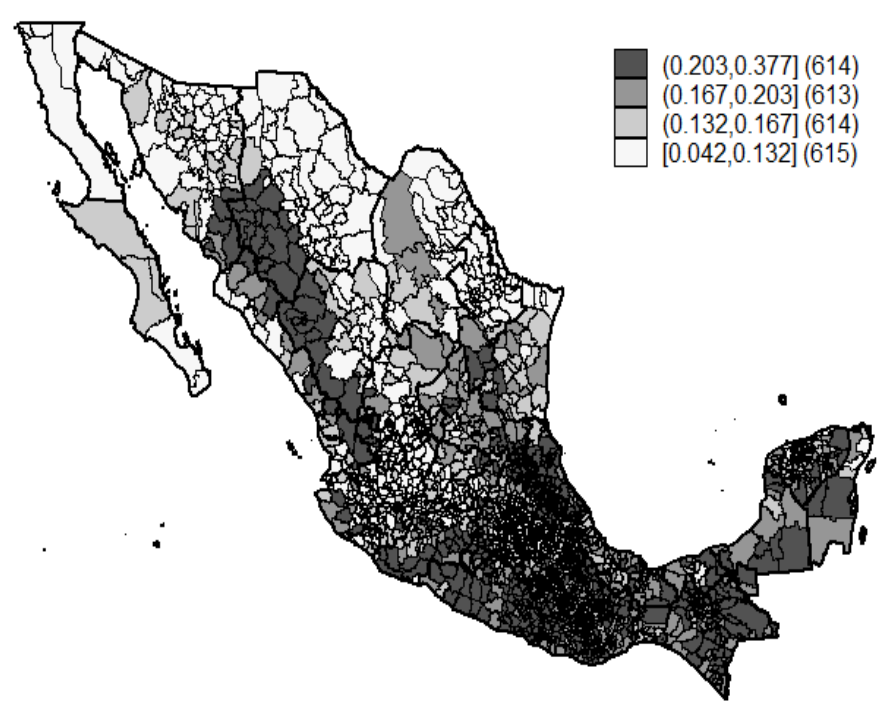

Source: Authors' elaboration from census data (INEGI, 2010) using STATA 'spmap' command

Figure 2. Gini coefficient: Predicted probabilities and marginal effects

Average Predicted Probabilities

$$
\text { -- 6-12 yo - 13-15 yо - 16-18 yo }
$$

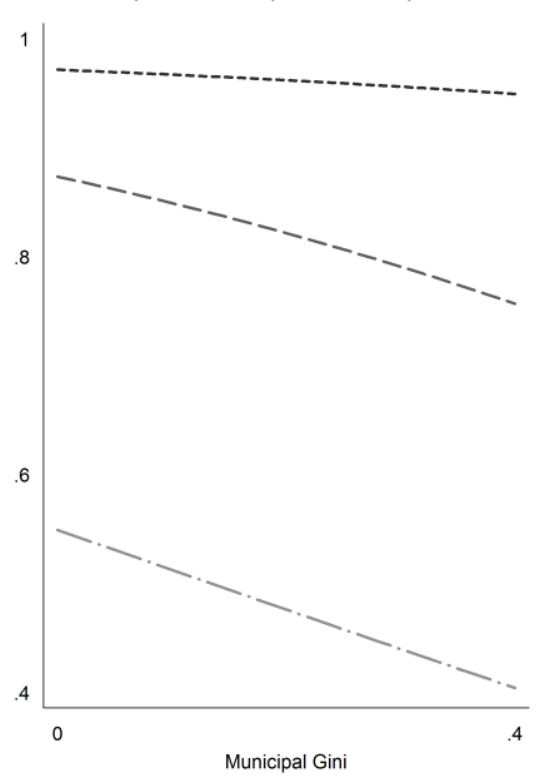

Average Marginal Effecs

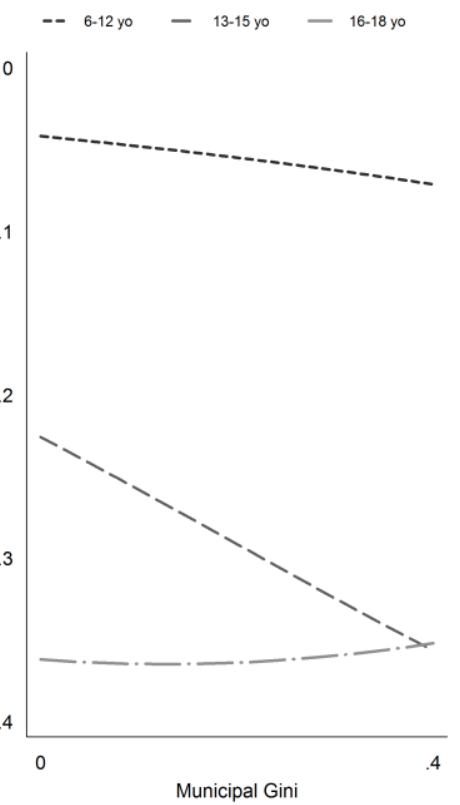


Figures 3. Predicted probabilities -

education at different levels of wealth (household level)

Ages 6-12

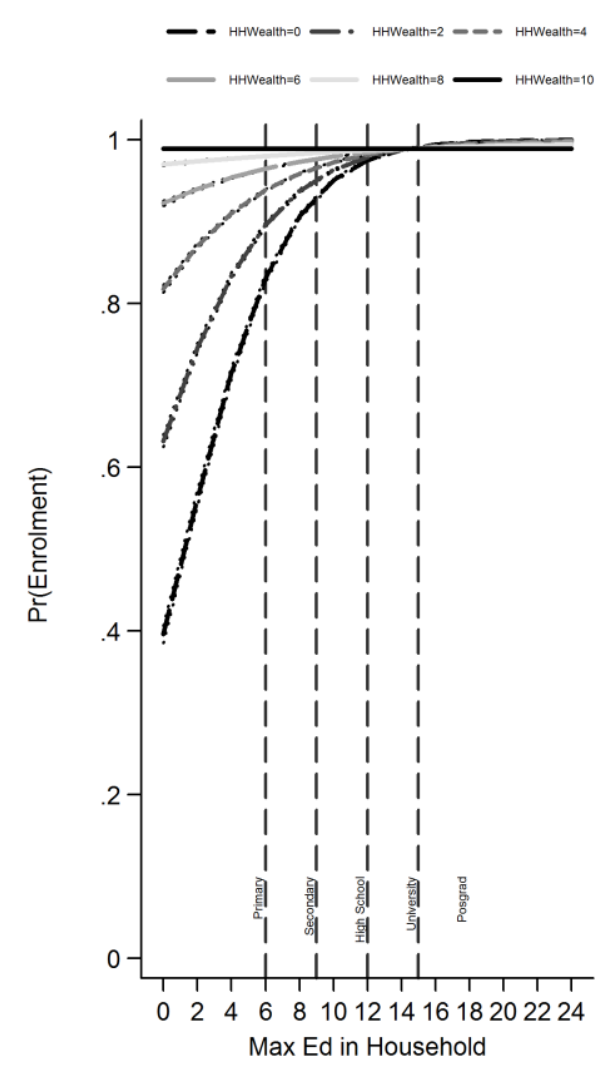

Ages 13-15

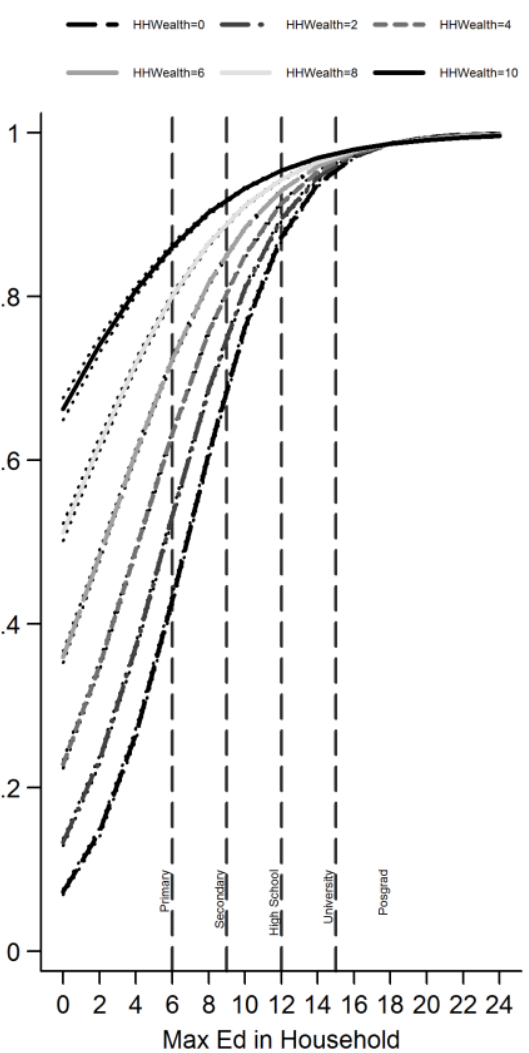

Ages 16-18

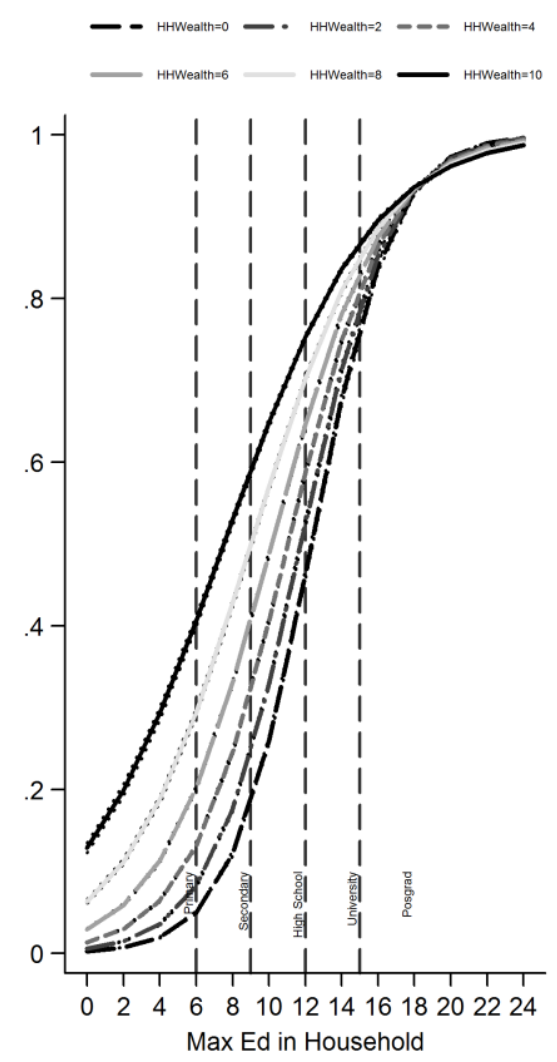


Figure 4. Scatter plot of municipal random effects

Ages 6-12

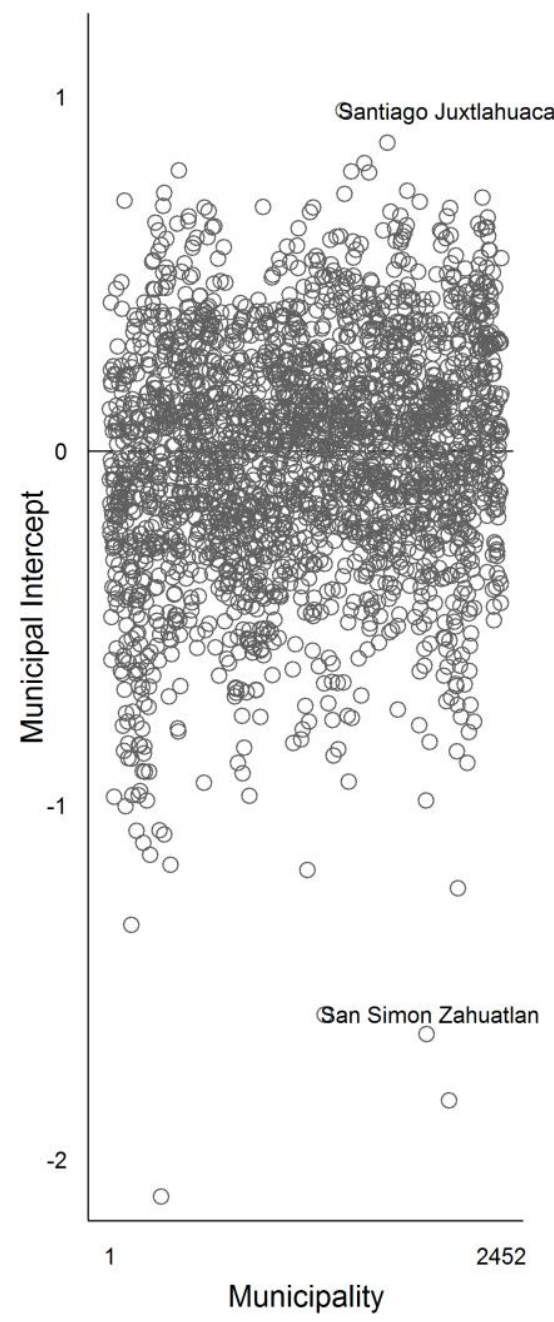

Ages 13-15

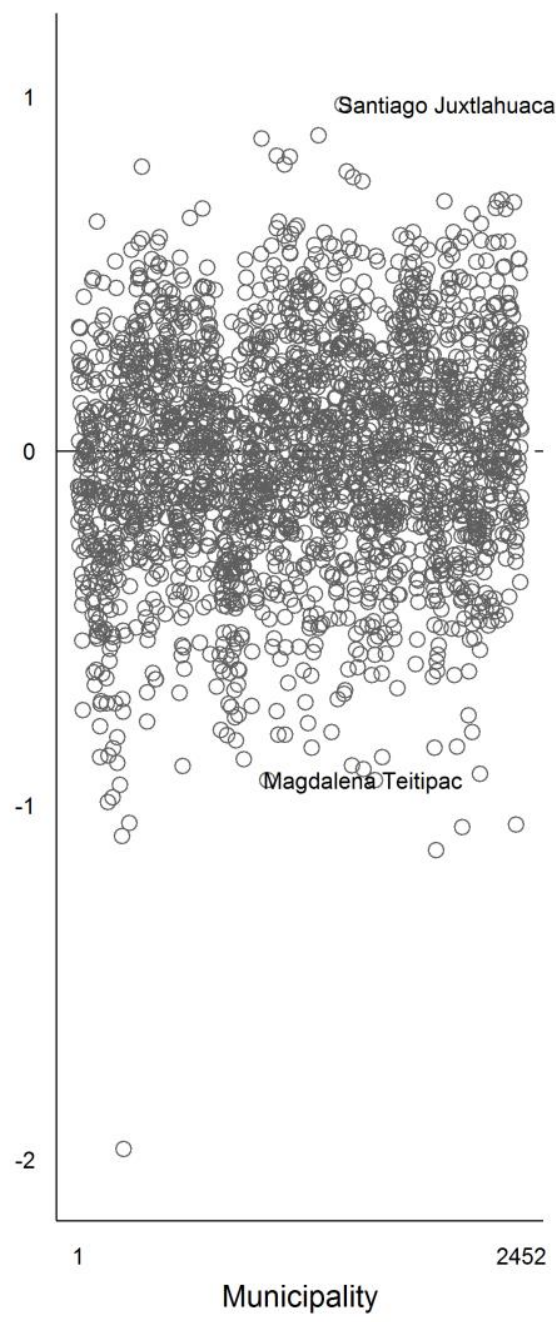

Ages 16-18

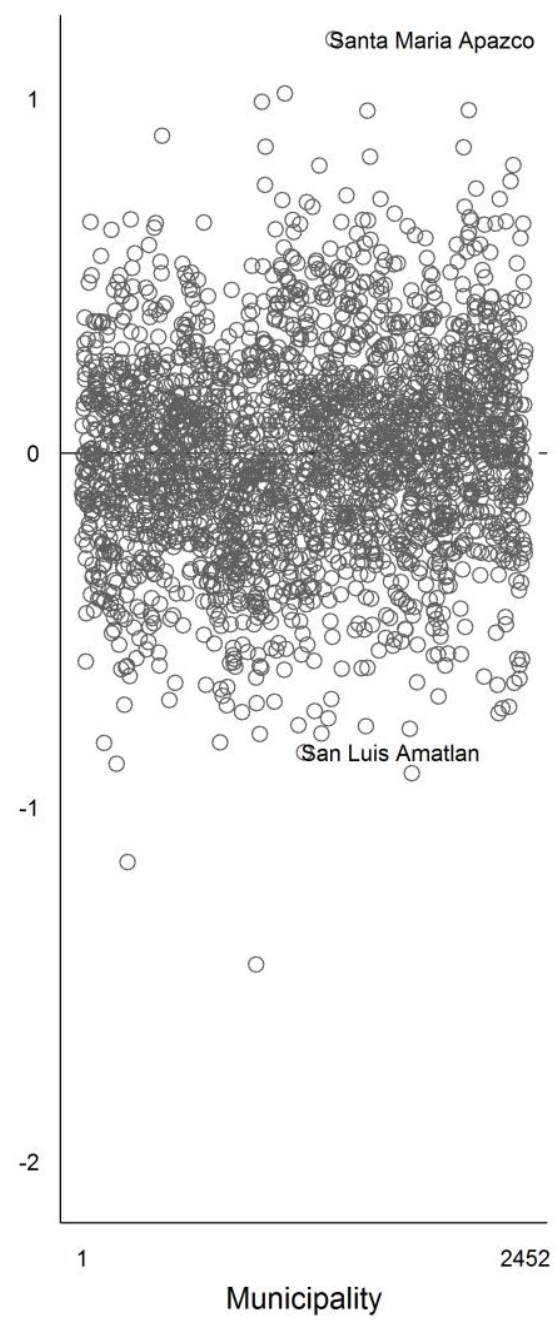


Figure 5. Municipal random effects - a comparison of neighbouring municipalities

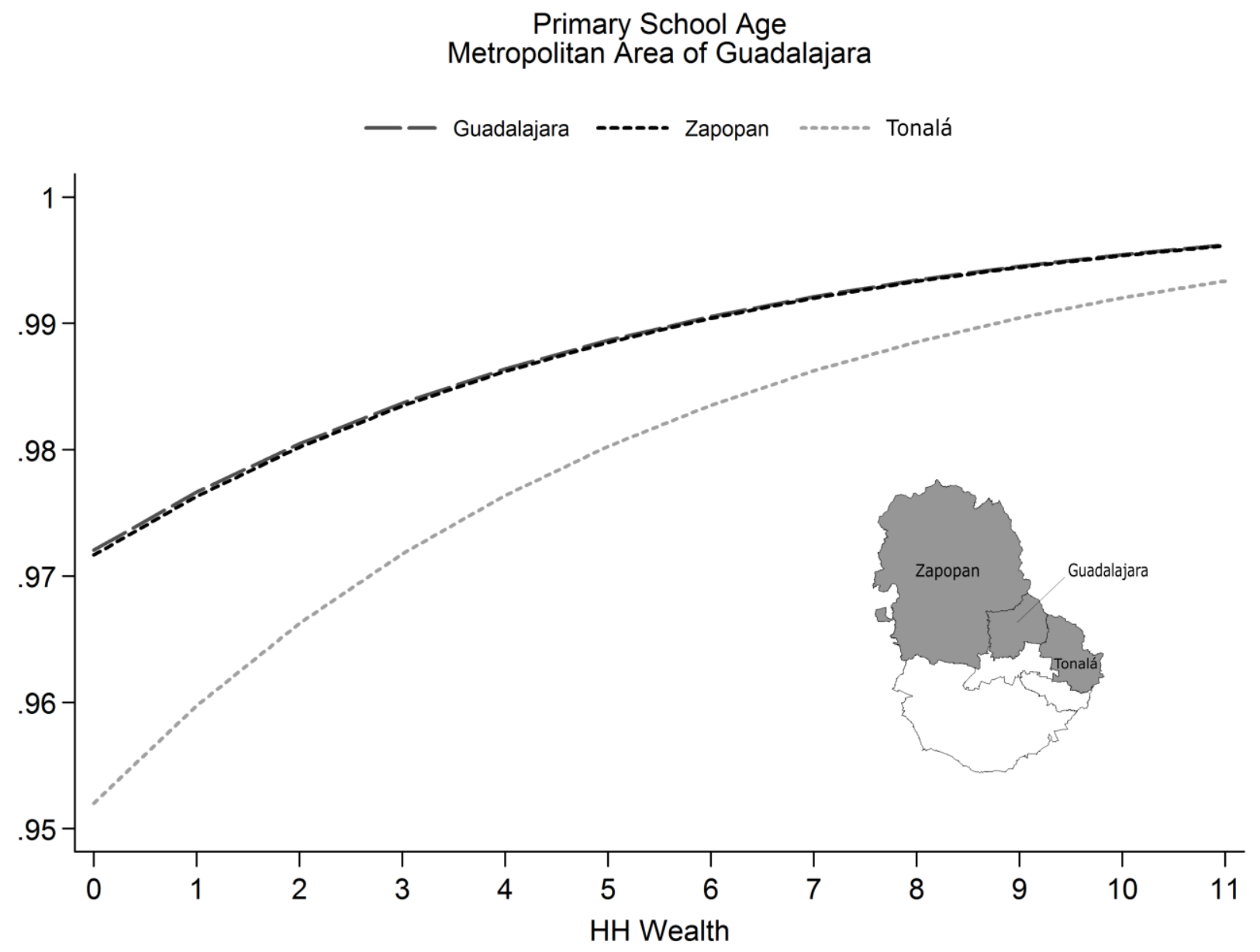


${ }^{\text {i }}$ See, for example, Knack and Keefer (1997), Takata (2003), Uslaner and Brown (2005), Elgar and Aitken (2011), de Vries, Gosling and Potter (2011), Loughnan et al. (2011), Neville (2012), Piff et al. (2012), Piff et al. Trautmann, van de Kuilen and Zeckhauser (2013) and Piff (2014).

ii See Peugh (2010), Reiter and Raghunathan (2007), and Gutiérrez, Carter and Drukker (2001) for technical discussions of the loglikelihood ratio test and Valentine, Verdes-Tennant, and Bonsel (2015) and Vu, Lee and Muhajarine (2013) for empirical applications. Results from our log-likelihood ratio tests (Chi2 statistics and the p-values) can be found at the end of our regression tables.

iii Standard Principal Components Analysis (PCA) assumes that the variables are multivariate normal. Following Kolenikov and Angeles (2009), we run PCA using polychoric correlations to better approximate the normality assumption and estimate the amount of variation explained by the first component. Finally, it should be noted that financial assets are not included in our measure of wealth because unavailable in the survey - we do not expect this to have created a relevant bias in out use of wealth as a predictor of school enrolment.

iv The migration index used in the analysis is calculated by the Mexican National Population Council on the basis of the percentage of households that receive remittances, percentage of households with members in USA, percentage of households with visiting members who live in the USA and percentage of households with returning members who lived in the USA between 2005 and 2010.

${ }^{\mathrm{v}}$ We remark that this interpretation of mean asset index relates to these specific models - as extensively explained by the body of literature quoted above. The use of mean asset index as explanatory variable in an OLS model where the dependent variable is municipal enrolment rates reveals (as expected) a positive and significant coefficient - results available upon request.

${ }^{\text {vi }}$ The introduction of an interaction term in a logit model allows for heterogeneity in the shape (rather than only in the position) of the curve representing the conditional probability that the dependent variable equals 1 as a function of the explanatory variable of interest; in other words, it allows this shape to differ at different levels of the interacted variable. This means that if a continuous variable is interacted with a dummy variable, we will have two possible shapes for this curve - one for each value of the dummy variable; if two continuous variables are interacted then we would have many (virtually infinite) shapes.

vii The analysis using age dummies is available upon request.

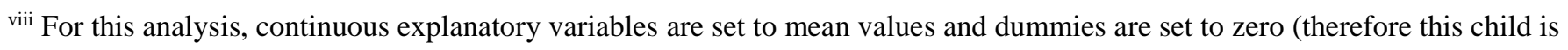
male, non indigenous, does not have any disability, etc.) 